\title{
STATE LEGISLATIVE RELIEF FOR THE MORTGAGE DEBTOR DURING THE DEPRESSION
}

\author{
J. Douglass Poteat*
}

\begin{abstract}
If a man owe a debt and Adad [the storm god] inundate his field and carry away the produce, or, through lack of water, grain have not grown in the field, in that year he shall not make any return of grain to the creditor, he shall alter his contract-tablet and he shall not pay the interest for that year. The Code of Hammurabi, King of Babylon, circa 2250 B.C. 1
\end{abstract}

The sensitiveness of state legislatures to pressure by debtor groups during hard times is traditional. This tendency has been both noted and regretted by "the truly wise as well as the virtuous"'2 of other generations. It was of such a time during the days of the Articles of Confederation that Chief Justice Marshall said, "The power of changing the relative situation of debtor and creditor, of interfering with contracts ... had been used to such an excess by the state legislatures as to break in upon the ordinary intercourse of society, and destroy all confidence between man and man. The mischief had become so great, so alarming, as not only to impair commercial intercourse, and threaten the existence of credit, but to sap the morals of the people and destroy the sanctity of private faith."3

But creditor interests have not been without their partisans in legislative halls. Again we have the word of the great Chief Justice that it was "to guard against the continuance of the evil" 3 " of such state legislative immorality that "that additional bulwark in favor of personal security and private rights-the contracts clause of the Constitution" found its place in the United States Constitution.

Indeed, it may be said that in broad outline, the history of debtor-creditor legislation in this country marks the turn of the economic cycle from periods of prosperity to those of hard times. This becomes strikingly apparent so far as the national legislature is concerned when we recall the history of bankruptcy legislation. ${ }^{5}$ For to

- A.B., 1923, LL.B., 1926, Furman University; J.S.D., 1933, Yale University. Member of the North Carolina and South Carolina Bars. Professor, Duko University School of Law since 1936.

The writer wishes to acknowledge the valuable research assistance of Mr. Joseph Laufer, member of the second-year class in the Duke University School of Law, in the preparation of this article.

I The Code of Hammurabi (Harper's $2 d$ ed. I904) \$48, p. 27.

${ }^{2}$ The phrase is that of Chief Justice Marshall in his dissent in Ogden v. Saunders, 12 Wheat. 213, 355 (U. S. 1827 ).

${ }^{3}$ Ibid.

sa Ibid.

"Madison, The Federalist (i788) No. 44; see also Beard, An American Interpretation of the Constitution (1913); Hamilton, In re The Small Debtor (1933) 42 Yale L, J. 473.

see, generally, WarRen, Bankruptcy in United States History (1935). 
observe the dates of the various bankruptcy acts is to note the incidence of those periods of hard times in our economic history which have distinguished themselves by their breadth and depth of reach. The act of $1800,{ }^{8}$ it is true, though following a period of economic collapse, was not designed primarily as a means of debtor relief. Modelled on the English law of that time, discharge from the debtor's obligations was an incident to be granted only in the rarest cases. But the next act ${ }^{\tau}$ passed in I84 $\mathrm{I}$ in the midst of a severe economic crisis carries a definite accent on debtor relief as a primary if novel function of bankruptcy. ${ }^{8}$ And although this law was on the statute books for only eighteen months, yet in that brief period 28,000 debtors were relieved of $\$ 445,000,000$ in obligations by the surrender of property worth hardly one-tenth that sum. ${ }^{9}$

And so, although in the act of $1867^{10}$ the "merchants and bankers in New York, Philadelphia and Boston" to whom those "rebel" debtors of the south had owed $\$ 300,000,000$ at the outbreak of the war gained temporary assistance in "collecting something of the millions of indebtedness due them from the rebel regions of the country"11-the industrial crash of 1873 , exceeding in extent and severity any the country had experienced, precipitated a demand for liberalization of the act in favor of the debtor and resulted in the amendment of $1874^{12}$ by which a composition device was added and discharge provisions were relaxed. Likewise, the perennial attacks on the present act, itself passed in the aftermath of the depression of 1893 , reflect the recurrence of normal "creditor times." They have been directed to strengthening the criminal and discharge provisions to prevent the "fraud and reckless speculation" permitted by the act in the original form. The Donovan reports of the early 1930's with their recommendations of reform pointed toward "creditor relief"; ${ }^{13}$ but with the persistence of the present depression with its focus again turned on debtor troubles, we have 1933 amendments to the act which in form and title at least are "for the Relief of Debtors."

The same tendency may be. observed in the debtor-creditor legislation of the states. Indeed, we may assume that, had the states been as free from constitutional

- 2 Stat. ig (1800).

${ }^{7} 5$ Stat. 440 ( $184 \mathrm{r}$ ).

"In debate on the bill Daniel Webster said: "I am free to confess my leading object to be to relieve those who are at present bankrupt, and who cannot be discharged or set free but by a Bankruptcy Act passed by Congress. . . . Between the want of power in the state and the want of will in Congress, unfortunate insolvents are left to hopeless bondage. . . . The cases of the hopeless debtor have been accumulating for a whole generation." 5 WEBSTER, Works (9th ed. 1856) 18.

${ }^{\circ}$ Cong. Globe, 27 th Cong., 3 d Sess. $(x 842) 69$.

${ }^{20}$ I5 Stat. 517 (1867). For the text of this law, see Cono. Globe, 39th Cong.,. 2d Sess. (1867) app. $228 \mathrm{et} \mathrm{seg.}$

11 Cong. Globe, 39 th Cong., 2d Sess. (1867) I I $86-1189$.

2 I8 STAт. 178 (1874).

${ }^{19}$ Donovan Report on Administration of Bankrupt Estates, House Comm. on the Judiciary, 7rst Cong., 3d Sess. (I93I) passim.

14 Act of March 3, I933, c. 204, 47 STAT. I467, I I U. S. C. c. 8. See especially $\$ 74$ (individual compositions and extensions) and $\$ 75$ (agricultural extensions and compositions, the Frazicr-Lemke Act). As revised by the Chandler Act, approved June 22, 1938, these amendments appear in the Bankruptey Act as follows: C. XI, Arrangements, $\$ \$ 300-400$; C. XII, Real Property Arrangements by Persons Other Than Corporations, $\$ \$ 400-600$. A new chapter (C. XIII) is added on Wage Earner Plans, $\$ \$ 600-700$. 
inhibition as Congress, more legislation in the debtor's interest would have resulted. A few laws were passed in the panic of $1837-1842.15$ A great many more were enacted by the southern states during the reconstruction period to alleviate the desperate financial condition in which the southerners found themselves after the war. ${ }^{16}$ With little exception, however, although such acts were phrased in the language of remedial reform to avoid the hazard of constitutional negation, they were declared by the courts invalid nonetheless. ${ }^{17}$

The response of the state legislatures to the demands for mortgage debtor relief is therefore squarely in the national and state legislative tradition. By 1932 the hope of a quick upsurge of general prosperity had vanished and the mounting number of foreclosures with the expropriation of farmers and homeowners could not be longer ignored by the legislators. And as the economic strain was more widespread, so the legislative response of the states was more extensive than it had ever been before. But it was not until the debtor's financial ills had reached pandemic proportions that the legislatures of the states were induced to prescribe. By that time it was too late for preventives. A therapeutic was indicated. And this in the legal idiom is simply to say that a law to be effective had to be retrospective, not merely prospective. But it is precisely at this point that the contracts clause of the Constitution obtrudes, although by judicial interpretation it leaves a narrow field of competence untouched. Chief Justice Marshall, in the case of Sturges $v$. Crowninshield ${ }^{18}$ which came before the Court in I8I9, said "The distinction between the obligation of a contract and the remedy given by the legislature to enforce that obligation has been taken at the bar, and exists in the nature of things. Without impairing the obligation of the contract, the remedy may certainly be modified as the wisdom of the nation shall direct." And in an 1866 case $^{19}$ this language was amplified by the statement that: "It is competent for the states to change the form of the remedy, or to modify it otherwise, as they may see fit provided no substantial right secured by the contract is thereby impaired. No attempt has been made to fix definitely the line between alterations of remedy, which are deemed legitimate, and those which, under the form of modifying the remedy, impair substantial rights. Every case must be determined upon its own circumstances. Whenever the result last mentioned is produced, the act is within the prohibition of the Constitution, and to that extent void."

It is only against the background of this language that the miscellany of state debtor relief legislation is intelligible. For the area of legitimate state action staked

${ }^{25}$ Feller, Moratory Legislation: A Comparative Study (1933) 46 HaRv. L. REv. ro61, app. I.

${ }^{10}$ The following preamble of an act "for the relief of the people of Georgia" passed by the Georgia legislature, Laws $1865-1866$, no. 255, may be taken as an indication of the temper of the legislators of that period. "Whereas, During the late war, the state of Georgia has been overrun by the opposing armies; the accumulated crops and agricultural stock in great measure destroyed; the Confederate indebtedness held by the people in exchange for their products has become valueless; and obligations of the State eagerly sought after as a safe investment, have been repudiated; the accumulated capital of nearly a century, represented by slave labor, amounting to nearly $\$ 3,000,000$, has been destroyed and the prospect of successful agriculture, the basis of all value, now dependent upon the voluntary labor of frecdmen, is a question of doubt and experiment, Therefore," etc.

${ }^{17}$ Feller, supra note 15 , app. I.

${ }^{10}$ Von Hoffman v. City of Quincy, 4 Wall. 535, 553-554 (1866). 
out in the early decisions has undergone little variation since. As might be expected, to avoid constitutional censorship the states have phrased their laws in terms of remedial reform. But even so, as we shall observe, many of the laws so masked have nevertheless been declared trespassers on a forbidden domain.

The many acts, their amendments and the decisions of the courts construing them are too voluminous to press within the framework of a single article. The appendix will give the detail of the enactments by states with some of the more noteworthy decisions on the laws. The text of the article will accordingly be devoted to a more general treatment of the movement for mortgage-debtor relief as it is reflected in the state statutes and decisions. These statutes fall into three general groups: (I) the moratorium by which the courts are authorized to delay foreclosure proceedings for a definite period of time expressed in the statute; (2) the extension of existing redemption periods; and (3) the prevention of abnormally large deficiency judgments following foreclosure sales, either by sanctioning the fixation of an upset price below which the property may not be sold, or by requiring the determination of a "fair market value" by the court, which figure rather than the sale price must be credited on the judgment. Although these devices are dealt with separately, it should be noted that some states utilize all and some combine two in their statutes.

\section{The Moratorium}

The device for relieving the mortgagor which has received the widest acceptation during the present period of depression is the moratorium. In all, 28 states have passed such laws. At first the legislatures seemed loath to deal drastically with existing mortgage foreclosure procedure. Coupled with this reluctance, it may be assumed, was the expectation that if foreclosures were enjoined for the period of the dark days of early 1933 the inevitable return to normal times would set all things right. At any rate, we find the first steps in the direction of mortgagor relief timid indeed. The Arkansas act, approved in February of 1933, seems to reflect this attitude in its provision for a postponement of the filing of answers in foreclosure proceedings for a period of three months. ${ }^{20}$ And even this step finds its rationalization not in the necessity for relief to mortgagors but "in the relief of congested dockets of the chancery courts." But with the continued downward spiral of deflation the movement for moratory legislation quickly gained momentum and stays of longer duration became the rule.

These laws with almost no exception are prefaced by a long preamble in which the desperate financial ills of the country are cataloged. And the world-wide economic depression is taken as the broad base upon which the exercise of an enlarged police power may find support. They are phrased in the language of remedial reform

- Ark. Laws 1933, no. 21; see also the Texas legislative sequence of that ycar. An act postponing sales under execution för four weeks because of the banking holiday (Laws 1933, c. 17) was followed by another before its expiration granting a further extension of short duration-crowded dockets being proffered in the statute as the explanation (id. c. 59). Another (id. c. I05) and then the Greathouse Moratorium Law (id. c. 102) authorizing the continuance of actions for the recovery of real property or foreclosure of liens for a period of 180 days stated as their justification the extraordinary financial emergency and depression. 
to escape collision with the contracts clause. And largely under the liberalizing influence of the United States Supreme Court's decision in the Blaisdell case ${ }^{21}$ the state courts have not withheld approval.

A notable exception, however, is found in Texas. In an earlier generation its supreme court as a preface to a liberal interpretation of its debtor exemption law, had boasted of the fact that "from the early-days of the Republic to the present time [1878] Texas has been the refuge of the unfortunate of other countries."22 But in 1934 when the legislature, declaring a state of emergency, undertook under its police power to authorize judges of the district courts to grant continuances and stays of execution in foreclosure suits, ${ }^{23}$ it was told in an opinion by the state supreme court that such action in the debtor's interest transcended the bounds of legitimate endeavor under the Texas Constitution. ${ }^{24}$ And confronted by this judicial intransigence the Texas legislature made no further efforts to devise mortgagor relief.

Most of those states in which the moratory statutes have been accepted without constitutional objection or which have met and overcome such objection, have extended by subsequent enactment the force of the laws. Not a few, however, have permitted them to lapse. ${ }^{25}$ The common practice has been to grant to the outstanding act a lease of life sufficient to carry it into the next legislative term so that if conditions at that time warrant an extension it may be granted with no interruption of the stay. Sixteen state legislatures have so acted, the present acts expiring by their terms on various dates during 1938,1939 and $1940 .^{28}$ These extensions are premised on the assumption that the emergency which called into being the exercise of this extraordinary legislative authority still persists and economic conditions demand as strongly as ever that their provisions be continued. The statutes are temporary by their own terms. Indeed, it is precisely this feature on which their constitutionality depends. The Supreme Court of the United States in the Blaisdell case, calling to its support the language of an earlier precedent ${ }^{27}$ to the effect that a law "depending upon the existence of an emergency or other certain states of facts to uphold it may cease to operate if the emergency ceases or the facts change even though valid when passed," has held that "it is always open to judicial inquiry whether the exigencies still exist upon which the continued operation of the law depends."28 And while "the declaration by the Legislature as to the existence of the emergency is entitled to great respect, it is not conclusive"; ${ }^{29}$ and there have been skeptical voices raised in at least two supreme courts of the states questioning the validity of emergency legislation in a period no longer of that complexion.

"2 Home Bldg. \& Loan Ass'n v. Blaisdell, 290 U. S. 398 (1934).

Black v. Rockmore, 50 Tex. 88, 96 (1878).

${ }^{21}$ 'Travelers' Inc. Co. v. Marshall, 124 Tex. 45, 76 S. W. (2d) Iooy (1934). See Comment (1934) 13 Tex. L. Rev. 78.

$\approx$ Del., Idaho, Ill,, Kan., Md., N. H., N. C. (various local laws), Okla., S. C., Tex., Vt.

${ }^{29}$ Ala., Ariz., Cal., Iowa, La., Mich., Minn., Miss., Mont., Neb. (unconst.), N. Y., N. D., Ohio, Pa., S. D., Wis.

\footnotetext{
${ }^{27}$ Chastleton Corporation v. Sinclair, 264 U. S. 543 (r924).

2 Home Bldg. \& Loan Ass'n v. Blaisdell 290 U. S. 398, 442 (1934).
} 
In early I933 the Nebraska legislature imposed a stay upon foreclosure decrees. ${ }^{30}$ This moratorium was to expire March X, 1935; but by subsequent enactments in 1935 and in 1937 it was extended to March $1,1939 .{ }^{31}$ The constitutional validity of the I933 act and its 1935 amendment was not made the subject of inquiry by the Nebraska Supreme Court though the statute was sanctioned by construction and application. ${ }^{32}$ In 1938, however, the court emerged from its self-imposed judicial moratorium to declare the 1937 act unconstitutional, grounding its decision on the observation that the "temporary emergency ... which had given vitality to the earlier mortgage laws in 1937 has ceased to exist."33 Mr. Justice Eberly speaking for the court said: "It appears that there is no crisis now prevailing which involves a general paralysis of business and finance, and that the unfortunate condition now confronting us is strictly a 'continued depression." "34 Accordingly, the court denied the law its blessing.

Likewise in Mississippi the court has become skeptical of the constitutional validity of its moratorium which, initiated in $1934,{ }^{35}$ has been subsequently renewed. The last renewal of this act, ${ }^{36}$ approved March 16,1938 , extended its operation until May I, 1940. In May of this year the Mississippi Supreme Court in the case of Atlantic Life Insurance Company v. Klotz ${ }^{37}$ observed as follows: "We think it may be now seriously questioned whether any such emergency continues to exist in this state as will support the further operation of the re-enacted so-called moratorium law, especially as to deeds of trust and mortgages given before the passage of these statutes. ... Courts take judicial knowledge of general conditions throughout their territorial jurisdiction, and we must begin to have some comprehension, as everybody else who is observant, that general business conditions have now returned to that which is as nearly normal as will perhaps ever again exist upon the general average in this section. It may, therefore, well be now inquired whether there is constitutional warrant for the further continuance of the enforcement of said moratorium laws." But since appellant did not press the question in argument, the court was content to "go no further in response to it than is said in the foregoing paragraph."

But the instances just noted are, after all, exceptional. Indeed, it is mainly in this fact that their interest lies. The courts of most of the moratory states under the pressure of the Blaisdell case have shown no disposition to deny either the severity or the persistence of the depression on the assumption of which the laws have been extended. This has forestalled constitutional demolition. It has also served to shift the scene of action from the field of legislation to that of judicial construction and application. Reference to the experiences of the states outlined in the appendix will indicate in some detail the degree of interaction between court and legislature. The situation has, moreover, brought out the residual power in the judiciary to narrow

\footnotetext{
${ }^{\infty}$ Neb. Laws 1933 , c. 65 .

32 See, e.g., Howarth v. Becker, 128 Neb. 580,259 N. W. 505 (1935).

so First Trust Co. of Lincoln v. Smith, 277 N. W. 762 (Neb. 1938).

st Ibid.

${ }^{39}$ Miss. Laws $1938, \cdot$ H. B. No. 152.

\& Miss. Laws 1934, c. $247 ;$ id. 1936, c. 287.
${ }^{37} 81$ So. 519 (Míss. 1938).
} 
the reach of legislative action, the exercise of which is exemplified in the sketchy picture which follows of the process in a single state, Iowa.

The moratory legislation in the debtor's interest undertaken by the Iowa legislature in $1933^{38}$ consisted of two devices: ( $\mathrm{I}$ ) pending foreclosure suits were continued until March I, I935, the mortgagor being required to pay an amount determined by the court as the reasonable price of possession during this period; and (2) unexpired redemption periods were likewise extended, the owner being entitled to possession in the meantime, if he apply income from the property to the payment of taxes, indebtedness, etc.

Before the expiration date of these acts, both were further extended to March $\mathrm{r}$, 1937. ${ }^{38}$ With this exception little material change was made in the amendments.

It is a judicial commonplace that in construing these acts, the mortgagor is given the benefit of the doubt, and it was early said that "the granting of the continuance is to be the rule under the statute" unless the mortgagee shall convince the court of good cause to the contrary. ${ }^{10}$ But this did not mean "that the purposes and intent" of the act was to give relief to property owners hopelessly insolvent for whom there could be no possible rehabilitation. If a mortgagee could so define his debtor's condition "good cause" had been shown."

The Iowa statute contained no moral requirement comparable to that of New Hampshire that the petition for relief contain "a brief statement of his (the debtor's) past conduct in meeting his legal obligations and liabilities."42 But at least the court proposed that when he "prayed for relief," the debtor's hat be held in "clean hands." 43 The court sympathetically observed that the "gift of prophetic vision ... was withheld from these lowly swains of the soil and the alluring mirage of perpetual prosperity led them deep into the uncharted desert of unprecedented depression. ... "44 But this was not to say that one who bought a farm within the moratorium period for speculative purposes could thus recoup with the aid of a prolonged legal stay. The moratorium was not for him. ${ }^{45}$

It was said in 1936 that to continue a mortgagor in possession whose payments are not sufficient to carry the property and who has no prospect of redeeming, violates the contracts clause. ${ }^{46}$ But when the legislature in 1937 extended the moratorium to

${ }^{39}$ Iowa Laws 1933, c. I79. $\quad{ }^{2}$ Id. I935, cc. I15, I10.

${ }^{40}$ Federal Land Bank of Omaha v. Wilmarth, 218 Iowa 339,252 N. W. 507 (1934).

11 Reed v. Snow, 218 Iowa 1165,254 N. W. 800 (1934). It was also held in Metropolitan Life Ins. Co. v. Laufersweiler, 221 Iowa 1008,267 N. W. 74 (1936), that a receiver of an insolvent bank is not entitled to moratory relief. He is not an "owner" in the sense of the statute.

${ }^{2} \mathrm{~N}$. H. Laws I933, c. I6r.

${ }^{3}$ Miller v. Ellison, 221 lowa II74, 265 N. W. 908 (1936). In Butenschoen v. Frye, 219 Iowa 570, 258 N. W. 769 ( 1935 ) the court said of a motion for a continuance: "The motion is addressed to a court of equity and good conscience for relief and succor for one who because of the emergency . . . is unable to prevent the immediate sale and sacrifice of the security pledged for the debt." But "He who seeks equity must do equity." And the debtor "was neither in distress nor would he acknowledge any willingness to do equity ..." and so was not entitled to relief.

"Mutual Trust Life Ins. Co. v. Dean, 22I lowa 591, 266 N. W. 282 (1936).

4 Equitable Life Assurance Soc. v. Kirby, 221 Iowa I150, 266 N. W. 520 (1936).

${ }^{45}$ John Hancock Mutual Life Ins. Co. v. Schlosser, 222 Iowa 447,269 N. W. 435 (1936). 
March I, 1939, although "applications for relief had to be in 'good faith" it was stipulated that a showing of the mortgagor's present insolvency or of the inadequacy of the security should not in itself constitute good cause for refusal to grant a continuance. ${ }^{47}$ And in the similar extension of the redemption statute the same language was employed. ${ }^{48}$

If the court has said that this new language adds "little if anything to [its own] judicial pronouncements," at any rate there is some evidence of a disposition to take the statute's language at face value. ${ }^{49}$ The case in which this was said presented a debtor in bankruptcy whose real property was rejected by that court as burdensome. His only other tangible assets were a tractor, also mortgaged, and a team of horses, and his debts exceeded his assets by more than $\$ 6,000$. But counsel had said that the land involved was in the "garden spot of the world" and the debtor had "the aid of the Good Samaritan neighbor" to help operate his farm, so the court was unable to say that the prospect of redemption was so remote as to justify withholding a continuance. ${ }^{50}$

Not all of the emergency laws have been confined in their operation to debts secured by real property mortgages or deeds of trust, though by far the great majority have been so limited. The most striking example of a general debt moratorium by which all laws related to the enforcement of any debt, public or private, except those due the United States, its agencies, or the state are suspended, is that of Louisiana. This act originally passed in $1934^{51}$ by the legislature (which under the Louisiana Constitution is given the power to authorize the suspension of the laws of the state), ${ }^{62}$ has been subsequently renewed without interruption and unless repealed or invalidated by the courts will continue in force until the twentieth day after the adjournment of the 1940 legislature. ${ }^{53}$

By its terms the State Bank Commissioner is made Debt Moratorium Commissioner and is authorized to set up the necessary administrative machinery. Following a hearing before him participated in by the debtor and his creditor, the Commissioner is authorized "to suspend all laws or parts of laws relative to the enforcement of any debt [as herein defined] . . . and to suspend all laws or parts of laws authorizing the reduction of such debt to judgment or the enforcement thereof, or the enforcement of any lien, privilege of mortgage securing the same ... for such period of time and under such terms and conditions as to the payment of any part of such debt, in principal or interest, by installment or otherwise . . . as may seem just, reasonable, fit and proper in each particular case involved." Jurisdiction of the Commissioner extends also to all pending judicial proceedings and upon the filing of his order in the court involved its process is thereby suspended, though an appeal from such order may be taken by any party interested to the district court which

\footnotetext{
7 Iowa Laws 1937, c. 80.

${ }^{4}$ Id., c. 79.

${ }^{5} \mathrm{Id}$. at 39.

Art. XIX, s. 5.
}

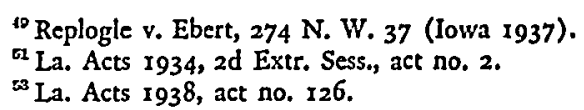


may not, however, enjoin any order of the Commissioner pending the rendition of a definitive judgment by the appropriate court of appeal. ${ }^{54}$

\section{Extension of the Rademption Period}

The plight of the hapless debtor under the early Common Law is well known. Imprisonment was his lot if he failed to pay, and the judges of that day seemed no less apathetic toward his troubles than the Law which they professed to serve. ${ }^{55}$ Nor was the mortgagor-debtor who defaulted dealt with much less harshly. His mortgagee held title to his land and default in payment meant immediate forfeiture of any chance to get it back. It is against this backdrop of ill fortune that the debtor's role as underdog is dramatized. And this may have served in part at least, to point up his demand that in the name of fair play restraint be imposed on his adversary mortgagee. At any rate, the courts did intervene in his behalf. The Chancellor, drawing his authority from Equity, tempered the shock of immediate expropriation by inventing the "equity of redemption," a doctrine which permitted the mortgagor to pay his debt within a specified period after default and thus regain the land which had passed to his mortgagee. And this, said a Lord Chancellor in 1762 , on the theory supported by "great reason and justice" that "necessitous men are not, truly speaking, free men but, to answer a present exigency will submit to any terms that the crafty may impose upon them."56

The judicial sale, no part of this early procedure-which still exists today in a few states as "strict foreclosure"57_was a later development, coming by way of statutory enactment. The period of redemption (somewhat similar to the equity of redemption ordained by the English Chancellor) which found its way into some of the foreclosure-by-judicial-sale statutes of the states comes into existence following the sale and continues for a stated period thereafter. ${ }^{58}$ Apparently in all but four

The act applies only to debts contracted prior to Isly 1, 1936; but such debts thereafter renewed or extended for the duration of the act are exempted from its operation. Mr. Sol Weiss, Jr., of the New Orlcans Bar, writing of this act under the title "Radicalism or Reform" in the Commercial Law Journal, May 1935, says that it is simple, informal, expeditious and free of costs. The procedure before the Commissioner as he describes it is not unlike that in bankruptcy, with the furnishing of schedules of debts and assets, participation of the creditors in the examination of the debtor and his books, and participation by all ereditors under the order of the Commissioner in the assets and income of the petitioning debtor under conditions scaling down debts and extending maturity dates during the duration of the act. The writer declared that "In actual practice, when a conditional moratorium is granted subject to stipulated payments, the Commissioner usually appoints one of the larger creditors as trustec to receive and distribute the dividends." He also declares that "Except where the application is made by the distressed owner of real estate where no early appreciation in value or income can reasonably be expected, the moratoria thus far granted have not exceeded a period of three or four months."

See also provision for local mediation board in the Wis. Laws 1933, c. 15, id. 1935, c. 319.

${ }^{*}$ In 1551 Chief Justice Mountague in the case of Dive v. Maningham, I Plowden 60, said of one committed to prison for debt "neither the plaintiff nor the sheriff is bound to give him meat or drink $\ldots$ if he has no goods, he shall live on the charity of others, and if others will give him nothing, let him die in the name of God, if he will, and impute the cause of it to his own fault, for his presumption and ill behavior brought him to that imprisonment."

"Vernon v. Bethell, 2 Eden $110(1762)$. See Durfee and Doddridge, Redemption from Foreclosure Sale-The Uniform Mortgage Act (r925) 23 Mrck. L. Rev. 825. ${ }^{67}$ Conn., Ill., Maine, Vt.

${ }^{69}$ An exposition of the statutory provisions of the several states relating to foreclosure and redemption may be found in 3 Jones, Mortonges (8th ed. 1928) ss. 1695-1746. In four states the period precedes the sale. 
states $^{58}$ the mortgagor enjoys possession during this period and in most states rentfree. ${ }^{60}$ The ostensible purpose of this mortgagor privilege is to afford a breathing spell during which the debtor may refinance his indebtedness or gather his growing crops. A less obvious but certainly important practical benefit, however, is the same as that sought to be accomplished by the acts discussed in the next section: the diminution of deficiency judgments. But here it is the mortgagee himself who diminishes the potential judgment, not the court. For generally the price of redemption is not the mortgage debt but the bid price at which the property was knocked down plus interest and costs. Accordingly for the mortgagee to protect himself against a loss of his security at less than its value, he must bid at least what he judges that value to be. And, of course, the higher bid thus induced lessens the amount of the deficiency which the mortgagor must make up. ${ }^{61}$

As these statutory provisions for redemption antedate the mortgages with which the courts have been concerned in this current depression period, constitutional objection does not intrude. ${ }^{62}$ But quite generally the existing redemption periods have been lengthened by the various states so as to fit into the moratory schemes adopted. And as the moratorium, acting retrospectively, must undergo the censorship of the contracts clause, so these amendments must do likewise. ${ }^{83}$ The result is that while quite a few statutes in their original form make no requirement that "rental value or income from the property" accruing during this statutory respite be applied on the debt, the recent statutory extensions do require this appropriation. The statute of Minnesota ${ }^{64}$ may be cited as typical. For, having received the constitutional sanction of the United States Supreme Court at an early date in the Blaisdell case, it has furnished the pattern which most of the statutes have followed.

By the law of Minnesota, passed long before the depression struck, a mortgagor might redeem his foreclosed property within a year after sale if foreclosure was by advertisement, or within a year after confirmation of sale, if by action. And the Minnesota Supreme Court had held that during such period the mortgagor's right to possession also included the rents and profits from the property. ${ }^{\circ 5}$ When, however, in I933 because of the "public economic emergency" existing in the state, the legislature moved to extend unexpired redemption periods, the act which it passed required the mortgagor "to pay all or a reasonable part of such income or rental value, ... toward the payment of taxes, insurance, interest, mortgage or judgment

\footnotetext{
${ }^{2}$ Ala., Ore., Tenn., N. Mex. Cf. however N. Mex. Laws 1934, Sp. Sess., c. 26, whích provides that in suits brought after March 15th of any year the mortgagor (erroneously "mortgagee" in act) may not be dispossessed from farm land until the crop is harvested, unless the instrument provide otherwise.

${ }^{00}$ For a statutory example, sec infra note 69.

The-South Carolina Legislature in 1932 (Iaws I932, no. 877) made use of this device obviously for the purpose suggested by enacting a simple statute providing that tha bidding at a judicial sale shall remain open for a period of thirty days, during which the bid may be raised by any person other than the mortgagee.

${ }^{2}$ A conventional statement of the law is given in 6 R. C. L. 365 (1915): "The general rule is that the law in force at the time a mortgage is.executed, with all the conditions and limitations it imposes, is the law which determines the force and effect of a mortgage."

a Jones, Mortgages $\$ 1694$ and cases cited. ${ }^{6}$ MinN. STat. (Mason, 1927) $\$ 9626,9643$.

Orr v. Bennett, 135 Minn. 443, 161 N. W. 165 (1917).
} 
indebtedness at such times and in such manner as shall be fixed and determined and ordered by the courts; ...." ${ }^{66}$ And one recalls that it is in this requirement of the act and the limitation on its own existence that the Supreme Court's opinion in the Blaisdell case found its main support for a judgment of constitutional validity.

The phrase in the emergency amendment is that "all or a reasonable part of such income or rental value" shall be applied on the mortgage debt. And this would seem to permit a wide judicial discretion in determining the proportion of income to be applied on the debt; and a number of the state courts have so construed the language. In South Dakota, however, the Supreme Court has held that the legislature in using these words "intended that the full value of the possession should be received by the mortgagee in every case, from one source or another." And an order "directing the payment of less than all of the income or rental value" would receive the court's approval only on a "showing that the mortgagee had received or would thereafter receive the remainder of such value from some source other than through a direct payment of the rental or income."Bz

Moreover, this device has not altogether escaped the ban of unconstitutionality though it is not by way of the contracts clause that it has been applied. ${ }^{68}$ In this context the technique of constitutional denial adopted by the Kansas Supreme Court is as interesting as it is rare. In that state the owner-debtor is given the right to redeem property sold under execution or order of sale within 18 months from the date of the sale and in the meantime he is entitled to possession of the property rentfree. ${ }^{60}$

In 1933 by joint resolution ${ }^{70}$ a moratorium was declared "upon all periods of redemption from judicial sales which were running at the beginning of the present emergency created by the bank moratorium under federal order and which expire during the moratorium as defined in section 2 hereof." Section 2 limited the extension to six months with an authority to the governor to renew it for a like period. The governor exercised this power ${ }^{71}$ and before the period lapsed, a special session of the legislature again renewed the moratorium to March $1,1935 .^{{ }^{22}}$ In 1935 the legislature once more extended the period, this time fixing its terminus at January 15 , $19377^{73}$ Under all these acts the debtor was required to pay the reasonable income or rental value of the property, default for 30 days extinguishing his rights.

${ }^{\infty}$ Minn. Laws 1933, c. 339.

${ }^{\text {or }}$ Lund v. Eggleston, 279 N. W. 546 (S. D. 1938).

* The Supreme Court of North Dakota, in State ex rel. Cleveringa v. Klein, 63 N. D. 514, 249 N. W. 118 (1933) held its statute unconstitutional as violative of the contracts and due process clauses. The decision was rendered, however, prior to the Blaisdell case and following this decision the legislature reenacted another and more embracive statute in 1935 (Laws N. D., C. 242), and in 1937 this was continued. Laws 1937, c. 16r.

Ean. Gen. Stat. (1935) \$60-3439. To Kan. Laws 1933, c. 232.

7 This was interpreted as an unconstitutional delegation of legislative power which rendered that part of the act invalid in the cases of Oakland State Bank v. Bowlin, I4I Kan. 126, 40 P. (2d) 437 (1935), and Langworthy v. Kadel, I4I Kan. 250, 40 P. (2d) 443 (1935).

${ }^{72}$ Kan. Laws 1934, Sp. Sess., c. 3 .

3 Kan. Laws 1935, c. 226. Kan. Laws 1935, c. 225 provided an automatic extension of periods of redemption to March I, 1935 . 
The 1935 act became effective on March I and shortly mortgage debtors who had been enjoying the substantial respite afforded by the previous moratoria began taking the necessary steps to assure themselves of the new dispensation provided by its terms. Five such, whose properties had been sold under foreclosure during 1932 and 1933, on petition to the court obtained extensions of their redemption periods until January 15 , 1937. Whereupon there seems to have occurred a simultaneous collapse of the patience of the mortgagees who had taken no objection to the previously granted stays. With one accord they now appealed to the Kansas Supreme Court for relief from what they considered an imposition on their indulgence. Their appeals $^{74}$ resulted in a decision declaring the r 935 act unconstitutional and establishing an authority on the basis of which 24 cases were reversed the same day.

Inspiration for this "crack down" was drawn from an 1893 Kansas decision but mainly from an opinion of a federal district judge construing the moratorium of $1934^{75}$ in which it was said: "To uphold and enforce the Mortgage Moratorium Law of this state passed after rights of these parties had been finally settled by orders and decrees, as against this fixed and settled law of this case, would be in direct conflict with the settled law of both the state and the nation, would be unconstitutional and void as against the fundamental law of the land and the absolute rights of the parties as determined before the Act of the legislature relied upon was enacted."70 In quoting with approval this language, the Supreme Court of Kansas said: "We are not willing to yield the unbroken record of this court and most other courts in favor of the judgment of a competent court of record being res adjudicata and not subject to annulment or being set aside by a subsequent act of the Legislature, even on the theory of the existence of an emergency, especially when that emergency is a continuation of four consecutive ones culminating in a total extension of nearly four years." ${ }^{.77}$ Thus the legislative redemption extension passed by the 1935 act was declared invalid as an attempt on the part of the legislature to alter an order of court from which no appeal had been taken and which by that fact had become res adjudicata. $^{78}$

The net effect of this holding was to restrict the operation of each act to decrees rendered after its enactment, an indulgence of no value for, as we have noted, the normal redemption period in Kansas was 18 months.

Since attorney's fees incurred in foreclosure are not infrequently taxed as part of the costs payable by the redeeming mortgagor, it is of interest to note that two

"Kansas City Life Ins. Co. v. Anthony, and four other cases, 142 Kan. 670, 52 P. (2d) 1208 (1935).

"Supra note 72.

30 Phoenix Joint Stcck Land Bank v. Dewcy, 8 F. Supp. 678, 679 (D. Kan. 1934).

- Kansas City Life Ins. Co. v. Anthony, and four other cascs, I 42 Kan. 670, 680, 52 P. (2d) 1208, 1213 (1935).

${ }_{78}$ Apparently, however, the orders of extension are not so "void" that the mortgagee may recover the income or the reasonable rental value which the mortgagor had retained during the extended redemption period. New York Life Ins. Co. v. Slentz, 145 Kan. 849, 67 P. (2d) 522 (1937); Union Central Life Ins. Co. v. Pletcher, I 44 Kan. 359, 58 P. (2d) II58 (1936). 
states, Idaho and North Dakota, have sought to impose a control on the amount of the fee charged. ${ }^{79}$

\section{The Deficiency Judgment Act}

The legislative and judicial history of the mortgage as a credit instrument reflects, in the long view, a tendency more favorable to the debtor than to the creditor. As an incident of this trend we observe the appearance of the procedure of foreclosure by judicial sale which has as its justification the assurance to the mortgagor of the surplus over the mortgage debt which the sale of the property brings. Yet this confers on the mortgagor a right which is valuable only when it is not needed-in an expanding market. ${ }^{80}$ In a period of abnormal deflation the judicial sale of property mortgaged during a period of prosperity will likely produce not a surplus but a deficit. And as the surplus is payable to the mortgagor, so the deficit is payable by the mortgagor. For the primary credit obligation is the note to which the mortgage is merely security; and if full payment of the note is not accomplished by the sale of the security, the creditor is entitled to look to other assets of the debtor for satisfaction. These "other assets" are subjected to the payment of the unpaid portion of his debt by a deficiency judgment which is measured by the difference between the sale price and the amount of the debt. And so the judicial sale, dependent for its effective operation upon a normal market and competitive bidding, in a period which furnishes no buyers-and so no bidders-may become an instrument of oppression by which the mortgagee may be treated to a windfall and the mortgagor made to pay his debt twofold. There is in fact no hint of the unusual in the many judicial sales held throughout the country during the first few years of the depression at which the single bidder was the mortgagee to whom the auctioneer, after a futile effort to whip up a bidding enthusiasm among the few other mortgagees present, knocked down property worth thousands of dollars on a bid of a mere $\$ 100 .{ }^{81}$

${ }^{70}$ An Idaho statute of 1937 (Laws 1937, c. 64) which repeals similar acts passed in 1935 (Laws 1935, cc. 7, 106) stipulates that redemption may be accomplished by "paying the purchaser the amount of his purchase with interest at six per cent (a reduction from a former ten per cent), taxes and attorney's fees ... " which must be "proven by affidavits of the attorney who has received and the person who has paid the fee. ..."

The action taken by the North Dakota legislature in 1933 may foreshadow a general movement for legislative control of attorney's fees charged in simple mortgage foreclosures. For that year the legislature reduced the attorney's fee taxable a' costs to $\$ 25$ which-somewhat gratuitously-he was denied the right to split with his client (Laws 1933, c. 154). Not only so. To collect this amount the good faith of his employment had to be proved. By the 1937 amendment (N. D. Laws 1937, c. I60) the right to a fee was limited to a resident lawyer of the state. And the strain on his honesty is relieved by omitting proof of good faith-simply making the violation of the statute a misdemeanor.

${ }^{W}$ If the property may be sold at a profit or for an excess over the mortgage debt, this may be better done at private sale by the mortgagor who may thus liquidate his debt. Accordingly as a device to preserve the debtor's equity in the mortgaged property, one may-assume that the judicial sale rarely functions.

E In Federal Title \& Mitge. Guaranty Co. v. Lowenstein, Ix3 N. J. Eq. 200, I66 Atl. 538 (1933), the Chancellor notes that on the date of the sale of the property thercin involved there were 29 sales foreclosing first mortgages. His tabulation shows that the decrees fixing the amounts due ranged from a low of $\$ 2,902.44$ to a high of $\$ 41,787.36$. Yet with the exception of one bid of $\$ 5,800.00$ against a decree of $\$ 8,475.77$ (and two bids at $\$ 200$ and $\$ 600$ ), all the properties were knocked down on bids of $\$ 100.00$. And he continues: "The record of sheriff's sales above recited and which is but a fair example of everyday 
It would seem that a court which had set itself a precedent for inventiveness in the creation of the equity of redemption to relieve against the forfeiture of a mortgagor's land would not doubt its authority to deal with the inequities inherent in the situation just alluded to. But this tradition of the early English Chancellor seems not to have been generally inherited by his contemporary American counterpart. Since, however, the sale's validity depends upon its confirmation by the court, a measure of control is permitted within the framework of orthodox equity doctrine. Confirmation may be withheld if the bid is so low as to "shock the conscience of the court." ${ }^{22}$ It is impossible to say just what disparity between value and bid price will provide the necessary shock. But "mere inadequacy of the price bid at the sale is not sufficient to authorize the trial court to refuse to give its approval." 83 True, "If there are other things in addition to inadequacy of price the court may refuse to confirm." But "General conditions resulting from the economic situation which has prevailed for the past few years is not a sufficient fact or circumstance, in addition to inadequacy of price, to justify a refusal to confirm." the court has been confined to ordering a new sale at which it is assumed a fair price will be obtained. It is hardly likely, however, that if the unconfirmed sale produced only a single bidder-the mortgagee-he can be induced to raise his bid at the second sale unless competition compels it. Accordingly the result of judicial intervention at this point may be simply to add the costs of successive sales to the mortgagor's debt.

Some courts, it is true, have borrowed from equity receivership practice the fixing of an "upset price" and have applied this to the simple mortgage foreclosure procedure. ${ }^{85}$ But again unless the upset price is bid, the court has no alternative but to order a resale and thus increase the costs. Indeed these techniques invoked in the debtor's interest may help him little if at all. Accordingly, we have a few courts, unwilling to be hemmed in by the inadequacy of old formulas and at the same time denying their dependence on legislative authority, which have broken through the conventional equity idiom and have asserted for themselves an inherent competence to deal with the new demands of this period.

cccurrences throughout the country, speaks eloquently of present day conditions and of which the court takes judicial notice. ..."

${ }^{52}$ For a typical statement of the principle, see the recent case of Fox v. Nelson, 133 Neb. 903, 277 N. W. 795 (1938) in which a number of supporting authorities are cited.

\$3 Washington Mutual Savings Bk. v. Horn, I86 Wash. 75, 56 P. (2d) 995 (1936); 3 Jones, MorrGAGES, $\$ 2108$, in support of a statement in the text to the same effect, lists a number of cases from the various state courts.

${ }^{86}$ Washington Mutual Savings Bk. v. Horn, I86 Wash. 75, 56 P. (2d) 995 (1936). See also Bolich v. Prudential Ins. Co., 202 N. C. 789,164 S. E. 335 (1932), in which the court answers in the negative its question: "Does the depression or unprecedented scarcity of money for ordinary transactions or enforced stagnation of the real estate market constitute an equity sufficient to warrant a court in restraining the exercise of the power of sale in a trust deed?" Lipscomb v. New York Life Ins. Co., 138 Mo. 17, 39 S. W. 465 ( 1897$)$ in which the court says: "However strong our sympathies may be enlisted for the unfortunate victim of hard times, they cannot furnish a basis for equity jurisdiction; and such courts cannot and ought not to be made the instruments of speculation in the future values of property even for the benefit of the unfortunate." See also Nelsen v. Doll, I24 Neb. 523, 247 N. W. 44 (1933).

*Wilson v. Fouke, 188 Ark. 811, 67 S. W. (2d) 1030 (1934). 
The most notable example of this assertiveness is that reflected in the decision of the Wisconsin Supreme Court in the case of Suring State Bank v. Giese. ${ }^{86}$ Here the trial court had refused to confirm a sale of property mortgaged for $\$ 2,000$ and bid in by the mortgagee for $\$ 600$, except on the condition that a deficiency judgment against the mortgagor be denied. In upholding this decision, the Wisconsin Supreme Court noted a "power of a court of equity, without the aid of statute, to take one or all of three steps for the protection of the parties and the promotion of a fair solution of the difficulties." The first two-refusal to confirm a "substantially inadequate" bid and fixation of an upset price-though somewhat unusual, were conventional enough and, as has already been suggested, accomplished little in the debtor's interest. The third, however, moves toward a much less common procedure. It is said that the court in fixing the "upset price" may conduct a hearing, establish the value of the property (in which "usefulness" and "future value" must be given weight) and, "as a condition to confirmation, require that the fair value of the property be credited upon the foreclosure judgment."87 And, although the plaintiff is entitled to reject this condition and thus force a resale, the delay and expense of this alternative should go far toward making him amenable, especially in view of the risk that the court might deny confirmation to the resale.

Had the courts taken the lead furnished by this decision, ${ }^{88}$ it is possible that the many deficiency judgment statutes designed to accomplish the same purpose-and largely by the same procedure-would never have been enacted. Almost all, however, referred to the case only to repudiate it and hurriedly retreat to the safety of more orthodox authority. ${ }^{89}$ And so the legislatures of a number of the states turned

${ }^{80 .} 210$ Wis. 489,246 N. W. 556 (1933). See notes (1933) 42 YaLe L. J. 960; (1933) 27 ILL. L. Rev. 950.

"87 Suring State Bk, v. Giese, 210 Wis. at $493,246 \mathrm{~N}$. W. at 558 .

${ }^{89}$ Even the Wisconsin court seems to have become frightened by its own forthrightness. See the following subsequent decisions: Northwestern Loan \& Trust Co. v. Bidinger, 226 Wis, 239, 276 N. W. 645 (1937); Weimer v. Uthus, 217 Wis. 56, 258 N. W. 358 (1935). And see, Stone, Mortgage Moratoria (1936) II Wis. L. REv, 203, 216 and note.

${ }^{0}$ Morris v. Waite, I19 Fla. 3, 160 So. 516 (1935); Federal Land Bank v. Crombie, 258 Ky. 383, 80 S. W. (2d) 39 (1935); United Bldg. \& Loan Ass'n v. Neuman, I13 N. J. Eq. 244, I66 Atl. 537 (1933); Federal Title \& Mtge. Guaranty Co. v. Lowenstein, supra note 8I (1933); Mellen v. Edwards, 179 Wash. 272, 37 P. (2d) 203 (1934); State ex rel. Comm'rs of Land Office v. Harrower, 167 Okla. 269, 29 P. (2d) I23 (1934); Clinton v. First Nat. Co., 180 Okla. 410, 70 P. (2d) 6I (1937). In Kenly v. Huntingdon Bldg. Ass'n, Inc., 166 Md. 182, 170 Atl. 526 (1934), the court said: "It seems to us that it is not for the courts to adopt a moratorium for the legal rights of litigants." And in Provident Bldg. \& Loan Ass'n v. Pekarek, 52 Ohio App. 492, 3 N. E. (2d) 983 (1936), repudiation of the Suring case was on the ground that: "The Chancellor's powers are not so broad as that of an autocrat. His powers in this advanced and enlightened age of jurisprudence are somewhat limited." The Mississippi Supreme Court in Standard Lbr. \& Mfg. Co. v. Deposit Guaranty Bk. \& Trust Co., I69 Miss. 120, 152 So. 639 (1934), in declining to adopt the principle of the Suring case, observed: "Equity does not violate the law nor treat valid contracts as scraps of paper, nor raise a shield to accomplish that end; if it did, in times such as we now confront, its halls would be overcrowded and statesmen would not need to wrestle with its problems." Cf., however, Farmers etc. Savings Bk. v. Eagle Bldg. Co., 15I Misc. 249, 27I N. Y. Supp. 306 (1934), in which the Suring case is followed. It was likewise followed in Bank of Manhattan Trust Co. v. Ellda Corp., I47 Misc. 374, 265 N. Y. Supp. 115 (1933), a case which, however, was reversed sub nom. Jewett v. Commonwealth Bond Corp., 24 I App. Div. 13I, 27 I N. Y. Supp. 522 (1934), appeal dismissed, 267 N. Y. 554,196 N. E. 576 (1935). 
their attention to the problem, setting up acts to sanction judicial control which the courts had refused to assert for themselves.

Some of these acts have taken the procedure of the upset price made somewhat more respectable for simple mortgage foreclosures by the Suring case and have provided that the price so fixed or the "fair value" be credited on the judgment. Under this procedure the difference between a figure judicially determined-not the sale price-and the mortgaged debt measures the plaintiff's recovery. ${ }^{90}$

The deficiency judgment laws enacted during this period reflect an unusual uniformity both of form and technique. They adopt either the device of the upset price, which is also made the basis of a credit on the foreclosure judgment, or they provide for the determination of the "fair value" of the property, and require that this be so credited.

The typical language of these acts permits the court in ordering the sale to "take judicial notice of economic conditions and after a proper hearing fix a minimum or upset price at which the mortgaged premises must be bid or sold before confirmation of the sale." Or on a motion to confirm the sale the court may conduct a hearing to establish the value of the property and require, as a condition to the confirmation, that such value be credited on the judgment. And in determining this "fair value" the court may call to its assistance testimony' or sworn appraisals by disinterested experts.

Nearly all invoke as their major premise the emergency created by the depression. But not all have a time limitation comparable to the moratory acts. Those which do, form a part of the general moratorium scheme and are made to expire simultaneously with the general act. New York's act is of this type and its constitutionality has been grounded in its temporary character. ${ }^{91}$ The constitutionality of the Alabama act is similarly rationalized. ${ }^{92}$ Many of the acts, however, are not so limited. Accordingly, unless they are subsequently repealed or otherwise consigned to the legal limbo by the courts they will constitute a permanent addition to the foreclosure procedure.

Not a few states have specifically exempted instruments executed to the federal government or any of its credit agencies from the operation of their moratory laws, including the deficiency judgment provisions. Indeed, fear lest mortgage relief funds be withheld led the California legislature, by joint resolution, to have inquiry made as to the effect of a proposed deficiency judgment act on federal policy. ${ }^{.3}$

${ }^{\circ}$ Idaho, having followed the conventional method in its 1933 act (Laws 1933, c. 150) limiting the deficiency to the difference between "fair value" and the mortgage debt, in its 1937 act (Laws 1937, c. 3 ) spurns these nicetics of procedural formality and forthrightly and simply destroys deficiency judgments by denying its courts jurisdiction over them. See also Neb. Laws 1933, c. 41; N. D. Laws 1937, c. 159 in which, at $\$ 4$, the legislature delivers this ultimatum: "If the courts declarc this act unconstitutional insofar as it relates to mortgages or contracts in existence at the time of taling effect of the Act, they shall never consider its constitutionality with reference to mortgages or contracts entered into after the date when this Act becomes effective."

${ }^{2}$ Klinke v. Samuels, 264 N. Y. I44, 190 N. E. 324 (1934).

22 Mutual Bldg. \& Loan Ass'n v. Moore, 232 Ala. 488, 169 So. I (1936).

${ }^{2}$ The California Asscmbly adopted an unusual method of ascertaining the extent to which federal funds might take flight as a result of the enactment of a proposed act abolishing deficiency judgments. By Joint Resolution No. 33, filed with the Secretary of State March 15, 1937, Cal. Stat. 1937, Res. 41, the 
By making these acts retroactive in their operation the legislatures have thrown them squarely into the teeth of the contracts clause of the Constitution. It is not surprising, therefore, that at this point we find the highest constitutional mortality. The effect of a decision of unconstitutionality is generally to render the act impotent only so far as existing contracts are concerned-uncurtailed control of mortgages executed after the effective date being permitted. But a few courts have refused to allow even this narrowed competence. The Arkansas Supreme Court, for example, after vetoing the deficiency judgment act of the 1933 legislature ${ }^{94}$ as being violative of the contracts clause, went on to hold, by construction, that as to instruments executed after the date of the act it has no applicability. ${ }^{95}$

The West Virginia Supreme Court in its zeal to defend all mortgages-present and future-from legislative officiousness, has taken the unique position that the deficiency judgment act of its legislature ${ }^{96}$ constituted an effort by the legislature to impose on the circuit courts "a function nonjudicial in its nature and therefore not within the powers of those courts as defined in the Constitution." Article 8 of the Constitution provides that the courts "shall have such other jurisdiction, whether supervisory, original, appellate, or concurrent as is or may be prescribed by law." But the court said that these "supervisory powers can be only exercised over matters juridical" and that such a matter is not presented when, on petition for confirmation of a sale, the court is required to determine the adequacy of the price. ${ }^{97}$

The Pennsylvania deficiency judgment act has likewise been permanently interred though the judicial requiem is varied. The acts, of 1934 and $1935^{98}$ were invalidated as impairing the obligations of preexisting contracts. ${ }^{99}$ Point was also made of the violation of the special legislation clause of the Pennsylvania Constitution, ${ }^{100}$ but the court declined to consider its pertinence. Consideration was given to this point in 1938 when the court decided that as to mortgages executed after its date, the acts were declared unconstitutional on this ground. ${ }^{101}$ And for the same reason

fecteral credit agencies were requested to advise the legislature "whether or not in their opinion the adoption of legislation ... abolishing deficiency judgments would have a tendency to hamper ... or prevent the continued granting of the Federal Land Bank, etc., to the citizens of the state of California; ...." The board of the HOLC through its general counsel replied under date of April 2, 1937, expressing the belief "that such deficiency judgment legislation as you refer to is unwise public policy, puts obstacles in the way of the family deciding to acquire a home, and should be avoided. ..." "The deficiency judgment evil consisted of the wrong which resulted from auction block sales on a bid not representing fair value at all but a mere nominal amount and the taking of a deficiency for the remainder of the debt after the mortgagee had taken the property for such nominal value. This situation is avoided by the law now on the books in California requiring that full credit for the full, fair value of the property be given at the foreclosure sale and the deficiency judgment be taken only for the remainder. . . ."

${ }^{24}$ Laws 1933, act no. 57 .

Adams v. Spillyards, 187 Ark. 641, 61 S. W. (2d) 686 (1933). ${ }^{10}$ Laws I933, c. 34.

Staud v. Sill, I14 W. Va. 208, i7r S. E. 428 (1933), followed by Buckeye Savings \& Loan Ass'n Y. Smith, $11_{4}$ W. Va. 284 , I7I S. E. 650 (1933).

${ }^{\infty} \mathrm{Pa}$. Laws 1934, Sp. Sess., no. 243; Laws 1935, no. 503.

Beaver County Bldg. \& Loan Ass'n v. Winovich, 323 Pa. 483,187 Atl. 48 I (1936); Shallcross v. North Branch Sedgwick Bldg. \& Loan Ass'n, r23 Pa. Super. 593, I87 Atl. 819 (r936).

${ }_{100}$ Art. 3, 57, as follows: "The General Assembly shall not pass any local or special law . . . providing or changing methods for collecting of debts or the enforcing of judgments or prescribing the effect of judicial sales of real estate." ${ }^{101}$ HOLC v. Edwards, 198 Atl. 123 (Pa. Sup. Ct. 1938). 
the judicial veto was also applied to the 1937 deficiency judgment act. ${ }^{102}$ The court could find no justification for a classification which excepted land banks and the Federal Farm Mortgage Corporation from the provisions of the act. Nor could the court justify different treatment for mortgage judgment creditors and other judgment creditors. Accordingly, the act was invalidated. ${ }^{103}$

The casualty list does not, however, include all of the deficiency judgment laws which the legislatures have passed during this period. There is one conspicuous survivor whose validity has been upheld not only as to mortgages made since its date but also to those which were executed previously. The act is that of North Carolina, passed in $19333^{104}$ And the opinion of the United States Supreme Court in Richmond Mortgage \& Loan Corporation v. Wachovia Bank \& Trust Company, ${ }^{105}$ establishing its validity, may well point the direction which later state court decisions will take. ${ }^{106}$

By the terms of this act, if the obligee is the purchaser at the sale and sues for a deficiency, the defendant is permitted to show "as a matter of defense and set-off . . . that the property sold was fairly worth the amount of the debt secured by it ..." and so "defeat or off-set any deficiency judgment against him in whole or in part." And in approving this statute the Court said: "The contract contemplated that the lender should make itself whole, if necessary, out of the security, but not that it should be enriched at the expense of the borrower or realize more than would repay the loan with interest. . . ."

The mandate of the statute is that the property's "fair worth" be determined by the court and this phrase or its synonym "fair value" recurs throughout the statutes. Obviously to require the imposition of a "fair value" standard to foreclosure sales implies at once the existence of such a standard and its availability to the judge charged with applying it. "Market value" is irrelevant for, with the exception of forced sales, there has generally been no market; and this has also meant that the fixation of value by the bargaining of the free-from-compulsion seller and the freefrom-compulsion buyer has largely ceased to function. Nor is the highest bid at the judicial sale of more assistance. Here the presence of competitive bidding and a normal market are the guarantee of an accurate value. It is, of course, a recognition of the absence of these factors which has led to the statutes in question. Certainly the bid price may be taken into consideration by the judge in fixing the "fair value"; but it must remain to other circumstances to carry the burden of evaluation.

A recital of these commonplaces merely serves to accentuate the anomaly of a "true value" concept as distinguished from "market value" in a price economy. ${ }^{107}$

${ }^{100}$ Pennsylvania Company v. Scott, 198 Atl. 115 (Pa. Sup. Ct. 1938).

${ }^{200}$ Sce notes (1937) 86 U. of PA. L. Rev. 295, and (1938) 4 U. op PITTs. L. Rev. 242.

${ }^{106}$ N. C. Laws I933, c. 275.

${ }^{200}$ Cf., however, Federal Land Bank v. Garrison, I85 S. C. 255 , 193 S. E. 308 (1937), in which the court adverted to Richmond Loan \& Mtge. Corp. v. Wachovia Bk. \& Trust Co., 300 U. S. 124 (1937), but declined to approve the South Carolina deficiency judgment act nonetheless. See also Alert Bldg. \& Loan Ass'n v. Bechtold, 199 Atl. 734 (N. J. Ct. Errors \& App. 1938).

${ }^{107} \mathrm{Sec} 2$ Bonbright, The Valuation of Property (1937) $837-848$. 
But anomalous or not, the judicial obligation is clear. From some source the hypothetical must be translated into the practical stuff of everyday court judgment. Or as one judge has put it, "The question is a difficult one but nevertheless must be determined."108

A formula of the New York court includes "evidence of the age and construction of the buildings on the premises, the rent received therefor, assessed valuation, location, condition of repair, the sale price of property of a similar nature in the neighborhood, . . . accessibility and all other elements which may fairly be considered as affecting the market value. ..."108 A.nd the court adds "with such evidence the trial court in the exercise of its best judgment should determine the market value . . in the existing circumstances."110. True, the same court in 1934 had observed that there is "no market value of real estate of any kind."111 But this, the 'court reminds us, was said in considering the constitutionality of the deficiency judgment act and "has no application to the question" of determining the standard of value required by its terms. ${ }^{112}$

Other factors have been added, such as "expectation of the return, in the not distant future, of a fairly normal market. ..."113 And it is in the same context that the court urges "the longer view . . . in order to arrive at a 'normal value' that avoids the pitfalls of inflation on the one hand and of deflation on the other."114

These subjective factors must undoubtedly weigh heavily in the balance struck, although they may represent nothing more than judicial wishful thinking or sentiment for the traditionally imposed-on debtor who cannot help himself. But in any event if the mortgagee is to be repaid his investment from the security which he holds, it is the market-present or future-which must support that payment. That the market will generally recover sufficiently to overcome depreciation and debt accumulation so that the mortgagee will thus be made whole, one may be permitted a doubt. There can be no doubt, however, that the "fair value" device, if the market

\footnotetext{
${ }^{109}$ Corn Exchange Bk. Trust Co. v. Ekenberg, I6I Misc. 62, 66, 292 N. Y. Supp. 142, 146 (1936). Illustrative of the gymnastics of guessing implicit in a judicial determination of "fair value" is the following: In Farmers' \& Mechanics' Savings Bk. v. Eagle Bldg. Co., I5I Misc. 249, 27I N. Y. Supp. 306 (1934), the trial judge fixed an upset price of $\$ 25,000$. The amount due on plaintiff's mortgage was $\$ 32,449.75$. He bid in the property at the sale at $\$ 25,000$, the upset price. The question of the deficiency judgment was not determined and this question is before the court in the decision reported in 153 Misc. 554,276 N. Y. Supp. 246 (1934). The judge determined the "fair and reasonable market value" by affidavits filed in the case. The officers of plaintiff insisted that "the property is not worth over $\$ 25,000$. ..." The values as shown by the affidavits of the defendant, however, were respectively $\$ 48,000$, $\$ 53,426, \$ 45,000$, "over \$50,000"; and that fixed by "an appraiser for the HOLC" was \$55,r92. The trial judge after "a careful examination of the affidavits submitted on behalf of the defendants" decided that "all things necessary for a fair valuation of the property have been considered by said appraisers" and determined that "the fair market value of the property at the present time is not less than $\$ 45,000$, or over $\$ 7,000$ more than all of plaintiff's claims. ..." And accordingly the deficiency judgment was denied.

${ }^{100}$ Heiman v. Bishop, 272 N. Y. $83,88,4$ N. E. (2d) 944,946 (1936).

${ }^{110} I d$. at 88,4 N. E. (2d) at 946 .

In Klinke v. Samuels, 264 N. Y. 144, I90 N. E. 324, 326 (1934).

112 Heiman v. Bishop, supra note rog.

${ }^{w}$ Corn Exchange Bank Trust Company v. Ekenberg, I6I Misc. at 66, 292 N. Y. Supp. at I46.

"Ibid.
} 
fails to stage this comeback, has effected a sharing of the loss between mortgagee and mortgagor by imposing a capital levy on the former and placing this to the credit of the latter.

Had it not been for the constitutional inhibition of the contracts clause it is likely that popular resentment against the many unconscionable deficiency judgments of the period would have shown itself in statutes abolishing this right altogether. ${ }^{110}$ The deficiency judgment statutes passed have, in form at least, stopped short of this drastic step. Instead, they have set up this "fair value" device, as one court has said, "to bring both mortgagor and mortgagee within the spirit of equity."118 And even in this form, as to preexisting debts, with little exception the laws have been struck down. One recalls, however, that these statutes are not temporary by their terms and as to mortgages executed after their date, their control is uncurtailed. Accordingly, they may represent the one permanent deposit of this period in the field of mortgage legislation.

The moratorium, on the other hand, avoids the problem of valuation by postponing it. But by adopting this course the legislatures have not thereby eliminated all the mortgage problems even for the present. Rather, they have created others hardly less burdensome which have been deflected into the laps of the judiciary. For relief is dispensed to the mortgagor through the medium of a court decree and while the statutes usually go no further than to require that taxes and reasonable payments on the debt condition a moratorium, the judges have proceeded on the assumptions that this does not require an automatic injunction against all foreclosure suits but only those in which the mortgagor shows himself worthy of relief. And, as we have seen, this duty to discriminate between the deserving mortgagor and his unworthy brother has conferred on the trial judge a degree of paternalism hitherto unknown to the mortgage relationship.

The policy of evasion which underlies the moratorium rests, of course, on the assumption that the economic condition which invoked legislative intrusion into the field of private contracts is merely temporary. Accordingly, if the mortgagor be tided over the present "crisis" the return of normal "good times" will solve his problems for him. Most are agreed, however, that such a prosperity is not now with us, and the extension of existing moratory legislation by some of the states into 1940 suggests no rosy optimism as to its early return.

While it would be fatuous to assert that the moratorium solves no problems, ${ }^{117}$

${ }^{115}$ See Report of the loint Legislative Committee on Mortgage Moratorium and Deficiency Iudgments to the Legislature, Jan. 31, 1938, N. Y. Leg1s. Doc. (1938) No. 58, p. 35.

${ }_{10}$ City Bank Farmers Trust Co. v. Combined Real Estate Interests, 149 Misc. 742, 268 N. Y. Supp. 150 (1933).

${ }^{127}$ The mortgagor to whom in the meantime the moratorium has assured a home would surely disagree. So also would the farmer whose land has thus been saved to him. And for those who because of the respite have been able to refinance through the HOLC or other federal agencies, the laws have provided a real solution to a financial problem. Not only so. The reluctant mortgagee on whom the moratorium has imposed a debt holiday is in a more receptive mood to the suggestion of his mortgagor 
it is nevertheless true that these statutes in a real sense merely temporize with a financial pathology. And this has given rise to the question, after the moratoriumwhat? ${ }^{118}$ There are those who insist that the shock of a sudden termination of the moratory stay on a real estate market already punch drunk from the depression would be more than it could stand. And to temper the impact it is suggested that during an extended moratory period the principal of existing mortgages be amortized at the rate of at least two or three per cent per year. ${ }^{119}$ But in most of the states now operating under moratory legislation the statutes have been in existence since 1932 or 1933. And by the time the present laws expire it is likely that in many cases it will be found that depreciation plus deflation has so widened the gap between the security's value and the loan that amortization on such a scale can never close it. Adjustment on a current market value basis would seemingly demand, therefore, curtailment at a much higher rate; and this, it is objected, cannot now be managed. $^{120}$

But will such a deflation result? The effect of wholesale foreclosures particularly in metropolitan districts would certainly be expected to produce this result. However, it will be recalled that there have been not a few states whose moratory statutes have lapsed. Whether this has resulted in a precipitate deflation of real estate values we do not know. Yet if the consequence had been as serious as that pictured by those advocates of indefinite extension, it may be assumed that the legislatures in the states concerned would have rapidly moved to reenact their moratoria. There seems to be no such movement.

To raise these quéstions is to make it apparent that no a priori answers may be had. Sooner or later some state like New York in which the mortgage problem has been most acute, and which on account of this fact has been holding back, must lift its moratorium. And the resultant experience will doubtless determine whether the others will follow or continue the present dilatory course until either inflation bails out the mortgagor or gradual liquidation reduces mortgage debt structures to workable dimensions.

For the latter alternative the new provisions of the Bankruptcy Act on Real Property Arrangements by Persons Other Than Corporations are available but offer no great promise. ${ }^{121}$ The principal purpose served by this new addition to the Bankruptcy Act is to afford the same relief to individual debtors as was formerly available to corporations under old Section $77 \mathrm{~b}$. By its terms both secured and unsecured debts may be scaled down under a rehabilitation plan. But the fact that confirmation is conditioned upon acceptance "by the creditors of each class holding two-thirds in amount of the debts of such class affected by the arrangement"122

\footnotetext{
that lower interest and even a reduction of the principal of his obligation be granted in consideration for getting rid of this legislative intrusion.

${ }^{110}$ The problem seemed ominous even in 1934. See Mischler, After the Moratorium-What? (1934)

I9 Iows L. Rev. 560. For a statement of the issue in a more recent context, see Report of the Joint Legislative Committec, supra note II5, at $32 \mathrm{et}$ seq. and 77 et seq.
${ }^{210}$ Id. at 43 .
${ }^{22}$ Pub. No. 696, 75th Cong., 3d Sess. (1938).
${ }^{200} \mathrm{Id}$. at 30,31 .
${ }^{120}$ Id. $\$ 468(\mathrm{I})$. 
means that the scaling of a mortgage indebtedness-if there is only one such in the debtor's schedule-may be accomplished only with the consent of the mortgagee involved. The promise of a more permanent debt revision and so a better chance of collecting on his security might induce a mortgage creditor so situated to agree to reduce his mortgage. Otherwise for the single mortgage debtor the new act offers no relief. Certain it is, however, that recourse to this procedure with a general scaling down of all obligations including mortgages should go a long way toward cushioning the impact of a wholesale foreclosure deflation.

The legislative liquidation of moratory acts now under way is regarded by some as affording occasion for provision of better laws relating to mortgages and foreclosures. In this legislative program the accent is on streamlining foreclosure procedure to step up its speed and cut its cost. And while this is primarily in the mortgagee's interest, it is said that the mortgagor will also profit because with an assurance of a rapid recovery of his principal the mortgagee will lend more money on less security at lower interest. But if the horse and buggy procedure in which we rode into the depression required the application of a legislative brake, one may well imagine how its more modern successor would fare in some future depression. Indeed, if recent experience means anything, it would seem that such procedure will likely survive the shock of depression only if elements of flexibility are introduced into the mortgagor's obligation or if the federal agencies which were set up after the event to provide financial relief to mortgagors and mortgagees in the present period are continued and expanded so as to anticipate this function in a future crisis.

\section{APPENDIX}

In this appendix reference is made to the state legislation enacted for the relief of mortgage debtors in the period of 193 1:-1938. Those statutes immediately directed to this objective have been included irrespective of whether they represent temporary emergency legislation or permanent additions to the mortgage laws of the enacting states. Statutes on collateral matters as, for example, acts postponing foreclosure of tax liens, although subserving the same general end, have been excluded. No attempt has been made to portray the statutory evolution in detail. The statements digesting the statutes indicate the latest stage in the development of the law and, in a number of instances, the content of earlier acts which have been superseded. Leading cases on constitutional issues and a few other decisions of interest on points raised by the acts have been noted.

In digesting the laws, accuracy and completeness of statement have been sacrificed to some degree in the interests of brevity, since the purpose of this collection is to provide merely a general indication of the legislative trend and a convenient reference for those who wish to pursue the subject in the statute books themselves. ${ }^{1}$ Because statutory compilations obscure year-by-year developments, citations have been given exclusively to the session laws.

Where the statutes have specified the dates of their termination, these have been indicated. No attempt has been made to indicate with precision the types of instruments which are subject to their terms although some variation on this point may be found

${ }^{1}$ A valuable compilation of comparable scope is Bridewell, Digest of State Moratorium Legislation and Judicial Interpretation of Sasise, U. S. Central. Housing Conas., Spec. Rep. No. 1, app. I (1936). 
among the statutes. A number of acts exclude from their operation mortgages held by the United States, its agencies and instrumentalities. Acts containing such provisions have been noted by appending an asterisk to the reference, although, again, caution must be given against certain variations in the exclusionary provisions. Not a few acts except mortgages given as security for public debts, an exception which, though not noted in the digests, is most frequently found in connection with the exception mentioned above. Frequently provision is made that the acts apply only to mortgages executed before a specified date. Such dates are indicated, but not the provision often accompanying them to the effect that mortgages otherwise subject to the act are excepted if extended or renewed for more than a year beyond the date given.

No legislation deemed appropriate for inclusion has been found in the laws of the following states: Colorado, Connecticut, Florida, Indiana, Kentucky, Maine, Massachusetts, Missouri, Nevada, Oregon, Rhode Island, Tennessee, Utah, Virginia, Wyoming.

ALABAMA. Deficiency Judgments. Laws 1935, act no. 146. Expires Oct. 1, 1939. Actions on debts secured by mortgages must, on motion, be stayed until foreclosure. Debtor may set off "fair and reasonable market value" of security. Muttul Bldg. \& Loan Ass'n v. Moore, 232 Ala. 488, 169 So. I (1936): act constitutional during emergency. Birmingham Trust \& Savings Co. v. Joseph, 234 Ala. 271, I75 So. 275 (1937): plea involving act demurrable unless it shows continuance of emergency.

ARIZONA. Moratorium. Laws 1933, c. 29; Laws 1935, c. 9; Laws 1937, c. 8; Laws 1937, 2d Sp. Sess., c. 17. Applies to mortgages made before March 4, I933. Expires March 4, I939. Court may continue foreclosures but not beyond March 4, 1939. In default cases mortgagor or mortgagee within ro days after judgments, may obtain court order permitting mortgagor to remain in possession, fixing "fair rental" which is paid to the clerk of court and applied by him on taxes, cost of maintenance, etc.

Deficiency JudGMrents. Laws 1933, c. 88. Not permitted unless mortgagee can prove that at time mortgage made value of security did not exceed amount remaining due. If proven, only entitled to judgment for difference between value as found by court or jury and amount due. Kresos $v$. White, 47 Ariz. 175, 54 P. (2d) 800 (1936): unconstitutional as impairment of contract. Perkins $v$. First Nat. Bk., 47 Ariz. $376,56 \mathrm{P}$. (2d) 639 (1936): act valid as to subsequent mortgages.

ARKANSAS. Moratorium. Laws 1933, act 21; Laws 1935, act 49; Laws 1937, act 221. Applies to mortgages made before Jan. I, 1933. Answers in foreclosure suits not due until three months after service. In fixing date of sale or confirming sale, court to consider debtor's condition, economic conditions, and fair price of property. Resale to be ordered if better price obtainable upon agreement to bid substantially higher. Wilson $v$. Fouke, $188 \mathrm{Ark} .811,67 \mathrm{~S}$. W. (2d) 1030 (I934): fixing of minimum sale price in decree sanctioned, although no statutory authority.

Deficiency Judgments. Laws 1933, act 57. Eliminated by requiring mortgagee to bid at least amount of the debt (or fair value if greater). Adams v. Spillyards, x87 Ark. 64I, 6r S. W. (2d) 686 (1933): unconstitutional as impairment of contract; construed not to apply to future debts.

CALIFORNIA. MORATORIUM. Laws I933, cc. 30, 263, 1057. Foreclosure sales of single dwellings under powers for default in principal postponed for brief periods. Laws 1933, c. 642 . Notice of default required to be recorded 3 months before exercise of power of sale, during which time default may be cured. Laws 1934, Extr. Sess., c. 1.* Sales under power or decree for default in principal postponed up to Feb. I, 1935. Laws 1935, c. 7. Thirty-day period for debtor to apply for stay for "just and equitable period" up to Sept. 1, 1935, provision to be made for compensation. Laws 1935, c. 348; Laws 1937, cc. 5, 167. Expires July I, 1939. Applies to mortgages made before Feb. I, 1935.* Within go days of recording notice of default, mortgagor may apply for postponement of sale under power or decree, relief to be granted where equitable, mortgagor to pay reasonable part of income or rental value, provision for upkeep, taxes, and insurance being required. Order terminable upon violation. Bennett v. California Trust Co., 6 Cal. (2d) 371,57 P. (2d) 914 (1936): burden of showing right to relief on petitioner.

Redemption. Laws 1935, cc. 7, 348; Laws 1937, cc. 5, 167. Expires July I, 1939. Applics to mortgages made before Feb. I, 1935.* Period to be extended on petition on same ground and conditions as provided for postponement of foreclosure sales under these acts.

Deficiency Judgments. Laws I933, c. 642; Laws 1935, c. 669. Not to be rendered before Sept. 1 , 1937 if recording of notice of default has not preceded sale under power at least one year. Brown $\nu$. Ferdon, 5 Cal. (2d) 226, 54 P. (2d) 712 (1936): unconstitutional impairment of contract when applied retroactively. Laws 1933, c. 790. Action must be brought within 3 months after sale under power. Christina v. McLoughlin, 18 Cal. App. (2d) 410, 63 P. (2d) I174 (x937); limitation constitutional. 
Laws 1933, cc. 642, 793; Laws 1937, c. 353. In action for deficiency or on note sccured by mortgage, amount recoverable is difference between debe and "fair value" of property. Rosenberg $"$. lanssen, ir Cal. App. (2d) 15, 52 P. (2d) 952 (1935): unconstitutional when applied retronctivcly. Laws 1933, c. 642; Laws 1935, c. 680. Not to be entered in cases of land purchase contracts or purchase moncy mortgages. Hales $\%$. Snowden, 19 Cal. App. (2d) 397,65 P. (2d) 847 (1937): unconstirutional when applied retroactively.

DELAWARE. Laws 1933, 2d Sp. Sess., c. 39. Expired March 1, 1935. Exccution process may be stayed for 6 months if mortgagor has applied to HOLC and latter has dcelared willingness to refinance.

GEORGIA. Deficiency JUdGments. Laws 1935 , p. $38 \mathrm{r}$. In forcelosures under power of sale no deficiency judgment unless sale reported to court for confirmation within 30 days. Confirmation only if property brought true market value at sale. No sale under power of sale except by sheriff after advertise. ment. Atlantic Loan Co. v. Petcrion, 181 Ga. 266, 182 S. E. 15 (1935): act unconstitutional as impairment of contract.

IDAHO. Monatoricis. Laws 1933. c. 124. Governor authorized to declare lcgal holidays limited to certain business and activities. Alliance Trust Co. \%. Hall, 5 F. Supp. 285 (D. Idaho, 1933): holiday declared on foreclosure proceedings, July 18-Sept. 14, 1934, unconstitutional impairment of contract.

Redexprios: Laws 1935, c. 36. Expired March 1, 1937. Applied to mortgages made before Feb. 20, 1935.* Court to grant such extension of period as it deemed just and equitable but not beyond March x, 1937, fixing reasonable rental valuc of property and payments to be made by mortgagor. Alliance Trust Co. $"$. Hall, II F. Supp. 668 (D. Idaho, 1935): act constitutional. Laws 1937, c. 64. Redemption period fixed at one year from sale. Interest payable reduced from 10 to $6 \%$ and attorncys' fecs limited to those actually paid by creditor or evidenced by his written obligation made within 6 months of sale.

Deficiency Judcments. Laws 1933, c. 150. Limited to difference between debt plus costs and "reasonable value" of the property. Laws 1937, c. 31. Entry forbidden in forcelosure cascs.

IILINOIS. Moratorium. Law's 1933, H. B. 507, p. 649. Expired June 30. 1935. Applied to inortgages on farms or homesteads held by insurance companies. Authorized Governor or Superintendent of Insurance with approval of former to stay foreclosures or cstend time of repayment. Levy $\nu$. Brondway-Curmen Bldg. Corp., 366 Ill. 279, 8 N. E. (2d) 67I (1937): Court may reject bid at foreclosure sale if grossly inadequate, fix up-set price and order resalc.

IOWA. MoRatorium. Laws 1933, c. I82; Laws 1933-34, Extr. Sess., c. I37; Laws 1935, cc. 115, 116; Laws I937, c. 80. Expires March I, 1939. Applies to mortgages made before Jan. I, 1936. Foreclosure may be stayed until March 1. 1939, upon application in good faith, orders being made concerning possession, and fair rental terms, income to be applicel on taxes, insurance, upkeep, etc. Present insolvency or present inadequacy of security not alone sufficient cause for refusing stay. (Sce comment, supra p. 524). Craig $\nu$. Waggoner, 218 Iowa 876,256 N. W. 285 (1934): moratorium constitutional.

Redemption. Laws 1933, c. 179; Laws 1933-1934, Extr. Ses5., c. 137; Laws 1935, cc. 110, 111; Laws 1937, cc. 78, 79. Expires March 1, 1939. Period may be cxtended until March 1, 1939, in all forcelosure actions on mortgages made before Jan. I, 1936. Present insolvency or inadequacy of security not alone sufficient cause for refusing extension. Des Moincs Jt. Stock Land Bk. $"$. Nordholm, 217 lowa 1319,253 N. W. 7or (1934): act constitutional. Laws 1933-1934, Extr. Sess., c. 135. Real property redeemed by debtor execution proof against foreclosure judgment.

Limitation on JUDGMENTs. Laws 1935, c. 108. Judgments obtained without forcclosure on debts secured by mortgage not subject to renewal by action, and, after 2 years, valid only as set-off or counterclaim. Applicable to future judgments and pending proceedings for, or based on, such judgments.

KANSAS. RESALE. Laws" 1933, c. 218 . Court may decline to confirm sale where bid is "substantially inadequate," or fix upset price, or confirm sale only if fair value be credited on judgnent.

Redexption. Laws 1933, c. 232; Laws 1934, Sp. Sess., c. 3; Laws 1935, cc. 225, 226. Expiration datc, Jan. 15, 1937. Applicable to mortgages made before March 2, 1934, if owner acquired title before Mareh 4, 1933, and has paid $1 / 3$ or more of purchase price. Period to be extended as "court may decm just and equitable." Court to determine income or rental value and direct payment to clerk of amounts payable in monthly instalments. Order terminable upon 30-day default. Kansas City Life Ins. Co. $v$. Anthony, 142 Kan. 670, 52 P. (2d) 1208 (1935): cxtensions of redemption period previously fixed by unappealed judgment unconstiutional (see comment, sufpra p. 528).

Deficiency Judaments. Laws 1934, Sp. Sess., c. 3; Laws 1935, cc. 225, 226. Not to be cnforced until extended period of redemption has expired.

IOUISIANA: Moratoruurs. Laws 1934, no. 159. Expired 2nd Monday in May, 1936. Applies to all mortgages made before July 13, 1934.* Temporary suspension of foreclosure procecdings but not beyond 
2nd Monday, May, 1936. Metropolitan Life v. Morris, 181 La. 277, 159 So. 388 (1935): moratorium constitutional, court refusing to consider constitutionality of section abolishing deficiency judgments.

General Dent Morntorium. Laws 1934, 2d Extr. Sess., no. 2; Laws 1935, 4th Extr. Sess.. no. I3; Laws 1936, no. 2; Laws 1938, no. 126. Expires 20th day after adjournment of regular legislative session of 1940 . Applies to all debts made before July I, 1936, not renewed or extended to expiration date of act." After hearing before Debt Moratorium Commissioner (State Bank Commissioner) debtor may obtain temporary suspension of laws for enforcement of debts, judgments, liens or mortgages, on such conditions as to payments in instalments of otherwise as to the Debt Commissioner "may seem just, reasonable, fit and proper in each particular case involved." (Sce comment, supra pp. 524, 525.)

Deficiency Judgments. Laws 1934, no. 159. During time act in effect (till and Monday in May, 1936) no deficiency judgments permitted. Saint Tammany Homestead Ass'n v. Bowers, 183 La. 987, 165 So. 176 (1935): held that Laws 1934, 2d Extr. Sess., no. 2 supersedes this act. Laws 1934, no. 28. Applies only to mortgages cxecuted after effective date of act. If mortgagee takes advantage of waiver of appraisal provision in mortgage and proceeds of sale insufficient, debt is discharged nevertheless. Home Finance Service 2 . Walmsley, 176 So. 415 (Ct. Apps. 1937): sale by mortgagee without appraisal forfcits right to deficiency.

MARYLAND. Laws 1933, Extr. Sess., cc. 56, 57; Laws 1935, c. 527. Salfs under Powers. Not to be exercised before June I, I 937 , unless consent of $25 \%$ of record holders of mortgage consent. U. S. Mtge. Co. 2 . Matthews, 293 U. S. 232 (1934), rev'g I67 Md. 383, I73 Atl. 903 (1934): held constitutional since pre-cxisting law governing contracts had made provision for such amendments.

MICHIGAN. Acts 1933, nos. 98, 122; Acts 1934, Extr. Sess., no. 20; Acts 1935, nos. 3, 4, 152, 158; Acts 1937, nos. 1, 2. Excepts mortgages after Feb. 14, 1933. Expires Nov. 1, 1938. Moratorium. Pending foreclosure actions postponed not beyond Nov. $\mathrm{I}, \mathrm{I938}$, on application unless good cause shown to contrary. Foreclosure proceedings and sales by advertisement transferable tc courts, and, if already confirmed, may be set aside where redemption period has not expired. Owners to remain in possession, provision being made for payment of fair rentals, taxes and insurance. Order terminable upon "substantial violation." Russell v. Battle Creek Lumber Co., 265 Mich. 649, 252 N. W. 561 (r934): held constitutional on authority of Blaisdell case. Union Guardian Trust Co. v. Harry \& Max Dunitz, Inc., 273 Mich. 607, 263 N. W. 751 (1935): rclief denied applicant who purchased during foreclosure. Equitable Trust Co. $v$. Solovich, 280 N. W. II $($ r938) : relief denied where no possibility of refinancing apparent. Virginian $J t$. Stock Land Bh. v. Hudson, 266 Mich. 644, 254 N. W. 234 (1934): burden of proof is on applicant and is not sustained where he was not diligent in meeting obligations or in seeking relief.

Redemption. Court may extend period (but not veyond Nov. I, r938) subject to same terms as provided for stay of foreclosure. Wade $v$. Farrell, 270 Mich. 562,259 N. W. 326 (1935): relief denied where no application therefor made when foreclosure was instituted. Detroit Trust Co. ข. Slack, 273 Mich. $46 \mathrm{r}, 263$ N. W. 429 (1935): relief denied second mortgagee where possibility of redemption remote.

UpSet Price. Acts 1933, no. 229. May be fixed by court in any foreclosure by action. Mutual Benefis Life Ins. Co. $v$. Wetsnian, 277 Mich. 322,269 N. W. I89 (1936): trial courts refusal to fix upset price not error in absence of clear and convincing testimony.

DFHiciency JudGMents. Not to be entered where foreclosure is by advertisement. If by action and if judgment is entered after Jan. I, 1933, not to be enforced before March I, 1937. Acts 1937, no. 143. Applies to forcelosures by advertisement after Feb. II, 1933. Defendant may show amount bid less than "true value" of property and difference between "true value" and bid shall be defense pro tanto. Issue to be determined by court without jury.

MINNESOTA. Laws 1933, cc. 44, 90; Laws 1935, c. 47; Laws 1937, c. 21. Expires March 1, 1939. Applies to mortgages made before April 18, 1933.* Morntorium. Mortgagor may obtain postponement of sale by advertisement and order that foreclosure proceed by action.

RESALE. To be ordered in foreclosures by action where sale price is unreasonably and unfairly inadequate in view of evidence relating to value of property and general economic conditions.

Redemption. Court may extend period, but not beyond March I, 1939, by order, which must provide for payment of income of property toward taxes, interest, insurance, or principal of debt. Period terminable upon violation of order. Blaisdell $v$. Home Bldg. \& Loan Ass'n, 189 Minn. 422, 249 N. W. 334 (1933), aff'd, 290 U. S. 398 (r934): "act held constitutional. Nat. Bank of Aitkin v. Showell, 195 Minn. 273, 262 N. W. 689 (1935): emergency held to exist in 1935.

Deficiency Judgments. None obtainable before March 1, 1939 .

MISSISSIPPI. Laws 1934, c. 247*; Laws 1936, c. 287; Laws 1938, H. B. No. 152. Expires May I, 1940. Applies to mortgages and judgments existing before March 4, 1933. Moratorium. Foreclosure under powers and execution sales may be enjoined if petitioner shows inability to refinance through United States agency. In foreclosure in chancery, sale may be postponed two years, court to determine income or 
rental value of property and order payment of all or part thereof toward taxes, insurance, interest, and upkeep. Order terminable on default for 30 days unless longer default caused by "good reason wholly beyond the control of the defaulter." Wilson Banking Co. Liquidating Corp. $v$. Colvard, 172 Miss. 804, r61 So. 123 (1935): act constitutional under Blaisdell case. Hooks v. Gann, I73 Miss. 23, I61 So. 702 (1935): relief available to junior mortgagee. Atlantic Life Ins. Co. v. Klotz, 181 So. 519 (1938): continuation of emergency questioned (see comment, supra p. 522).

Deficiency Judganents. No action to be maintained until extension expires.

MONTANA. MoRatorium. Laws 1933, c. I16. Expired March I, 1935. Stay of foreclosure actions till March 1, x935, in discretion of court, order to make provision for such payments of intercst, rents, profits, etc., as court deemed necessary.

Redexptzon. Laws 1933 , c. 150 . Purchaser at sale not entitled to possession of home of mortgagor during redemption period. Laws 1935, c. 122; Laws 1937, c. 73. Expires March 1, 1939. Applies to mortgages made before March 13, 1935.* Period to be extended "just and equitable time" up to March 1, 1939, mortgagor to pay all or reasonable part of income or rental value for taxes, insurance, interest, etc. Order terminable on $3^{\circ}$ days default.

Deficiency Judoments. Laws 1935, c. 2. Applies to mortgages made after Feb. 5, 1935. Not to be granted on purchase money mortgages. Laws 1935, c. 122; Laws 1937, c. 73. Expires March 1, 1939. Applies to mortgages made before March 13, 1935. Deficiency judgments not to be entered before expiration of redemption period.

NEBRASKA. MoRatorium. Laws 1933, c. 65; Laws 1935, c. 41; Laws 1937, c. 42. Expires March I, 1939. Applies to mortgages and sales made before March I, x934. Foreclosures may be stayed until March 1, 1939, orders being made concerning possession and fair rental terms, the income to be paid toward taxes, interest, insurance and upkeep. Actions on notes secured by mortgage may be stayed 9 months after ju'dgment, further stays being obtainable on conditions prescribed for staying foreclosures. First Trust Co. v. Smith, 277 N. W. 762 (1938): act unconstitutional as of Feb., 1937, under state constitution, emergency having expired (sce comment, supra P. 522).

Deficiency Judgments. Laws 1933, c. 41. Courts denied power to enter deficiency judgments.

NEW HAMPSHIRE. Laws 1933, c. 161; Laws 1935, c. 3. Expired June 15, 1937. Applied to mortgagcs made before June i5, 1933. Moratorium. Foreclosure stayed on showing of "unjust hardship" caused by abnormal economic conditions. Application must list mortgagor's liabilities and assets and state his past record in meeting obligations.

Redemption. Might be extended for such period as would not work unjust hardship on parties.

NEW JERSEY. DEFICIENCY JudGMENTS. Laws 1933, c. 82; Laws 1935, c. 88. Expiration date, July 1, 1938. Actions must be brought within 3 months after confirmation of sale, amount recoverable bcing difference between debt and "fair market value" as determined by court or 3 appraisers chosen by partics. Debtor not applying for this determination may redeem within 6 months from date of judgment. Vanderbilt v. Brunton Piano Co., II I N. J. L. 596, I69 Atl. I77 (1933): 1933 act unconstitutional as impairment of contract. Alert Bldg. \& Loan Ass'n v. Bechtold, I99 Atl. 734 (1938): though preamble declaring emergency was added and expiration date fixed, 1935 act also unconstitutional.

NEW MEXICO. Laws 1934, Sp. Sess., c. 26. In foreclosures on property whercon there is a growing crop, instituted after March 15, of any year, mortgagor (erroneously "mortgagee" in act) may not be dispossessed until crop harvested, and may retain crop. Instrument may provide othervisc.

NEW YORK. MORatoriux. Laws 1933, c. 793; Laws 1934, cc. 278, 357, 890; Laws 1935, cc. 1, 17, 318, 763; Laws 1936, cc. 86, 286, 611, 703; Laws 1937, c. 82, 713, 714; Laws 1938, c. 500. Expires Jan. 1 , 1940. Applies to mortgages made before July 1, 1932, except building and loan mortgages payable in instalments over yo or more years. New and pending foreclosures and actions on obligations secured by mortgage suspended during continuance of emergency where default is solely in payment of principal or instalment thereof. Mortgagee may apply to have any surplus earnings over fixed charges applied toward principal. Interest rate not to be increased upon maturity of obligation during emergency. Waiver of provisions declared against public policy. Loporto $v$. The Druiss Co., Inc., 268 N. Y. 699 , 198 N. E. 565 (1935); id., 269 N. Y. 677,200 N. E. 54 (1936) 299 U. S. 617: act constitutional.

Deficiency Judgments. Laws 1933, c. 794; Laws 1934, cc. 277, 562, 564; Laws 1935, cc. 2, 268; laws 1936, c. 87; Laws 1937, cc. 83, 705; Laws 1938, c. 501. Expires July 1, 1939. Applies to mortgages made after July 1,1932 . Where foreclosure action is begun or property sold during emergency no deficiency judgment unless plaintiff move for determination by court of the "fair and reasonable market value" of the property, the amount recoverable to be difference between judgment debt and such value of property, less prior liens. In actions on obligations secured by mortgage value of property may be set off against debt. Klinke $v$. Sammels, 264 N. Y. I44, I90 N. E. 324 (1934): act constitutional. 
NORTH CAROLINA. Moratorium. Public-Local Laws I933, cc. 74, 380, 525, 547. For two years foreclosures under powers or by action may be continued for one year from date of report or action. (Applicable to certain counties only.) Laws I933, c. 275. Foreclosure sales or confirmations may be enjoined to avoid irreparable damage, plaintiff to give bond against losses resulting therefrom. Woltz $v$. Asheville Safe Deposit Co., 206 N. C. 239 ; 173 S. E. 587 (I934): act constitutional. Whitaker v. Chase, 206 N. C. 335, 174 S. E. 225 (1934): injunction available to junior mortgagee.

Resale. Laws I933, c. 275. Court having enjoined confirmation may order resale, provided bond is given, or receiver appointed, and prior liens paid where necessary.

Deficiency Judgments. Laws 1933 , c. 36. Not to be granted on purchase money mortgages showing their purpose on their face. Notes prepared by sellers for this purpose must contain identifying provision. Public-Local Laws 1933, cc. 350, 425. Time to file answer extended two years. (Applicable to certain counties only.) Laws 1933, c. 275. Defendant may show as defense and set-off that property sold was "fairly worth" the debt secured or that "amount bid was substantially less than its true value." Applicable only to sales under powers not previously confirmed. Richmond Mtge. \& Loan Corp. v. Wachovia Bk. \& Trust Co., 300 U. S. 124 (1937) aff'g 210 N. C. 29 , 185 S. E. 482 (1936): act constitutional. Laws 1933, c. 529. Actions for deficiency must be brought within one year of date of sale.

NORTH DAKOTA. MoRatorrum. Laws 1933, cc. 155, 156, 158; Laws 1935, c. 242; Laws 1937, c. 161. Expires July I, 1939. Applies to mortgages made before Feb. 15, 1937.* Foreclosures may be stayed but not beyond July I, 1939, nor without requirement that reasonable payments on taxes, interest, etc., be made by mortgagor. Foreclosures under power of sale may be transferred, on petition, to courts. Resale may be ordered if court finds that bid price "unfairly inadequate." No deficiency judgments may be obtained during period of acts.

ReDemption. Laws I933, c. I57; Laws 1935, c. 242; Laws I937, c. I61. Expires July I, 1939. Extends redemption periods but not beyond July $\mathrm{I}, \mathrm{I939}$, and on condition that during extended period mortgagor pay reasonable amount on taxes, etc.

DEFiciency JUdGMENTS. Laws 1933, c. 155; Laws 1937, c. I59. "The court shall have no power to render a deficiency judgment." Purchaser at sale not entitled to possession of property or income therefrom until expiration of a year following sale. Though expressly not repealing the above acts, Laws 1935, c. 242; Laws 1937 , c. I6r, provide that no deficiency judgments obtainable until July I, 1939.

OHIO. Morstorium. Laws 1933, p. 227; Laws I934, p. 327; Iaws 1935, p. 10; Laws I937, S. B. I6. Expires April I, 1939. Applies to mortgages and other specific liens made before May 18, 1933. Court may order postponement of sale and enforcement of debt until such time (but not later than April I, 1939) as it may believe just and equitable in light of interests of the affected parties and of existing economic conditions. Current taxes, insurance and interest due after postponement must be paid, order being terminable upon default. Virginia $7 t$. Stock Land Bk. v. Shaffer, 7 Ohio Op. 186 (Ct. App., 1936): act constitutional but affords no relief after sale.

Deficiency Judgments. Laws 1937, S. B. 27. Judgments on debts secured by mortgages on dwellings for not more than two families to become null and void two years from date of act or judgment, whichever is later. Executions issued within such period not to be affected. Creditor's bill may be brought within four years.

OKLAHOMA. MoRatorium. Laws 1933, c. 16. Expired March 7, 1935. Time to answer foreclosure action extended 9 months; where answers were already filed, trials postponed 9 months. Continuances may be granted in discretion of court for not more than life of act ( 2 years) if mortgagor pays accruing interest or reasonable rental of property adequately secures debt. Roth $v$. Waterfield, I67 Okla. 209, 29 P. (2d) 24 (1933): arbitrary extension of time for answer unconstitutional as violation of due process and of state constitutional requirement that courts to be open at all times; discretionary continuances valid.

PENNSYLVANIA. Moratorium. Laws 1933, no. 137; Laws I935," no. 5; Laws 1937, nos. 225," 297." Expires March 31, 1939. All writs of execution may be stayed in discretion of court to avoid "serious inequity," subject to provision for payment of costs, taxes, interest, insurance, repairs, etc.

Deficiency Judgments. Laws 1933, Extr. Sess., no. 59; Laws 1935, c. 197. If mortgagee applies within 6 months, fair value of property to be credited on judgment; otherwise mortgagor may apply for entry of satisfaction. Beaver Bldg. E Loan Ass'n v. Winovich, 323 Pa. 483, 187 Atl. 481 (1936); Shallcross ${ }^{\circ}$. North Branch-Sedgwick Bldg. \& Loan Ass'n, 123 Pa. Super. 593, I87 Atl. 819 (1936): acts unconstitutional impairments. Laws 1937 , c. 37. Proceedings to reopen judgments satisfied under previous laws to be begun within 3 months after March 24, 1937. Laws 1937, c. 561.* Before issuance of execution on foreclosure, mortgagee must either release debtor from personal liability or apply for fixation of fair market value. If this amount is not bid at sale, court is to order successive postponements of sale, not to exceed 2 years. Pennsylvania Co. v. Scott, I98 Atl. II5 (Pa. Sup. Ct. I938): unconstitutional as violating state constitution prohibiting local or special laws (see comment, supra Pp. 533, 534). 
SOUTH CAROLINA. REDEMPTION. Laws 1932, no. 877; Laws 1933, no. 366 . Bids remain open for 30 days following foreclosure sale, during which anyone except mortgagee may raise bid. Not applicable unless deficiency judgment asked.

Moratorium. Laws 1934, no. 1214; Laws 1936, no. 1356. Expired Oct. 10, 1937. Aṕplied to mortgages made before March 2, 1934. Provides for appointment of conciliation boards to effect settlements between mortgagors and mortgagees. Foreclosures may be stayed, reasonable rental fixed and orders of salc conditioned or waiver of deficiency judgment.

Deficiency Judgrents. Laws 1933, no. 264. Within 90 days after advertisement mortgagor may have appointment of appraisers who shall report "true value" of property which is credited on the mortgagee's judgment. Applies to all mortgages present and future. Federal Land Bank w. Garrison, 185 S. C. 255 , I93 S. E. 308 (1938): act unconstitutional as impairment of contract.

SOUTH DAKOTA. Foreclosure by AdVertisement. Laws 1933, c. 135. Transferred to court on application of mortgagor. State ex rel. Northwestern Mut. Life Ins. Co. v. Circuit Ct., 61 S. D. 356,249 N. W. 63I (1933): held constitutional as affecting remedy only.

Redenption. Laws 1933, c. 137; Laws 1935, c. 178; Laws 1937, cc. 163, 207. Applics to mortgages made before Feb. 18, 1937. Period may be extended beyond one year (but not beyond March I, 1937) upon order requiring petitioner to pay all or reasonable part of income or rental value towards insurance, taxes, and interest and principal of debt and safeguarding against waste. Order terminable upon violation. Lund $v$. Eggleston, 279 N. W. 546 (1938): order allowing mortgagor to live rent free in apartment house otherwise rented reversed. (See comment, supra p. 527.)

Deficiency Judgments. Laws 1933, c. 138; Laws 1935, c. 150. Applies to mortgages made after Fcb. 2, 1933.* Not to be granted in cases of purchase money mortgages or mortgages foreclosed by advertisement. Laws 1937, c. 208 . "True market value" to be credited on judgment if obtained by mortgagee and if properly sold by advertisement. (1935 act not repealed).

TEXAS. Mor.trorium. Laws 1933, cc. 17, 59, 102, 105. Brief postponements of foreclosure sales. Laws 1934, 2nd Called Sess., c. 2. Brief postponement of foreclosure sales. Laws r934, 2nd Called Sess., c. 16. Expiration date, Feb. I, 1935. Stays in foreclosure suits and injunctions against sales under powers authorized on motion that sale would be "unfair and result in a loss," that property value substantially exceeds debt, and that reasonable income or rental value will be paid by mortgagor. Travellers Ins. Co. $\nu$. Marshall, 124 Tex. 45, $76 \mathrm{~S}$. W. (2d) 1007 (1934): unconstitutional as impairment of contract. (Sce comment, supra p. 521 .

Deficiency Judgments. Laws 1933, c. 92. "Actual value" of property to be credited. Six months limitation on actions and on issuance of execution. Langever v. Miller, 124 Tex. 80, $76 \mathrm{~S}$. W. (2d) 1025 (1934): unconstitutional as impairment of contract and invasion of judicial powcr. Texas Nat. Securities Co. $v$. Oldham, $88 \mathrm{~S}$. W. (2d) 621 (Tex. Civ. App. 1935): period of limitation invalidated as inseparable from rest of act.

VERMONT. Laws 1933, no. 30; Laws 1935, no. 49. Moratorium. Expired March 1, 1937. Stay of execution sales may be ordered by chancellor for not more than 3 months. On petition showing debtor's "past business record," that he is solvent, etc., period may be extended an additional 60 days.

ReDEMPrios. At time of foreclosure decree chancellor may extend redemption period "as may appear to him to be for the benefit of all parties interested."

WASHINGTON. Dfficiency Judgments. Laws 1935, c. 125.* Court may in its discretion fix upset price. Confirmation only if upset price or fair value of property is credited on foreclosure judgment. Only for excess of debt over upset price or fair value of property.

WEST VIRGINIA. Laws 1933, c. 34. SAles UNDER TRUst Deeds. Confirmation only if sale price reasonably adequate; otherwise resale may be repeatedly ordercd. Conveyances by trustecs without leave of court forbidden. Stated $v$. Sill, $\mathrm{II}_{4}$ W. Va. 208, 17 I S. E. 428 (1933): act unconstitutional as attempt to confer non-judicial powers on court.

WISCÓNSIN. Redempion. Laws I931, Sp. Sess., cc. 24, 29; Laws 1933, cc. 11, 15, 125, 240, 416, 474, 494; Laws 1935, cc. 319, 482, 506*; Laws 1937, c. 15; Laws 1937, Sp. Sess., c. 5. Expires April 1, 1939. Applies to mortgages on homes given before July I; 1939. Period of redemption may be cxtended to April I, 1940, upon orders for reasonable payments on taxcs, etc. (A mediation board was quasi-judicial, advisory functions discontinued in 1937.) Mutual Bldg. \& Sav. Ass'n v. Willing, 221 Wis. 563, 267 N. W. 297 (1936): 1935 moratorium constitutional.

Deficiency Judgrents. Laws 1933, c. 13; Laws 1935, c. 449. Upset price may be fixed. No confirmation of sale or deficiency judgment unless fair value of property credited on debt. Laws 1933, c. 125. Prohibits actions at law until after foreclosure. Hanater $v$. Republic Bldg. Co. 216 Wis. 49,255 N. W. I36 (1934): unconstitutional as impairment of contracts. Laws 1935, c. 506; Laws 1937, Sp. Scss., c. 5. Entry of judgments without foreclosure on debts made before Jan. 1, 1935, may be postponed for one year but not beyond March I, I939. 